\title{
From Capone to Boesky: Tax Evasion, Insider Trading, and Problems of Proof
}

\author{
Linda S. Eads $\dagger$
}

The efficacy of using the criminal law to discourage commercial and financial activity such as securities fraud and tax evasion has been questioned. Professor Eads agrees that such use of the criminal law should be scrutinized. However, she asserts that in concentrating on the theories underlying this use of the criminal law, commentators for the most part have ignored practical problems that arise in enforcing such laws. Studying tax-evasion and insider-trading prosecutions, she finds that courts have allowed and affirmed convictions based upon less than the constitutionally required evidence. A close reading of opinions indicates that this judicial leniency is due in part to the courts' perception that the prosecution put on as good a case as it could and in part to the courts' belief that the defendant was a wrongdoer. Although such a judicial response is understandable, this use of context without proper reference to principle subverts constitutional protections and leads to arbitrary decisions. Professor Eads concludes that courts should refuse to affirm diligent but constitutionally flawed prosecutions and thereby force legislatures to be more creative in remedying perceived ills. The Article ends on a cautionary note, examining recent legislative criminalizations of commercial behavior, determining that similar problems of proof will arise in these areas, and urging that courts not adopt the unconstitutional burden-shifting devices that they have resorted to in tax-evasion and insider-trading cases.

Both Congress and state legislatures are making increasing use of criminal sanctions to control complex commercial and financial activity. ${ }^{1}$

$\dagger$ Associate Professor of Law, Southern Methodist University. B.A. 1971, American University; J.D. 1975, University of Texas. I wish to thank my colleagues Walter W. Steele, Jr., Daniel W. Shunian, and Frederick C. Moss, and my former student, Mike Sanders.

1. A sampling of federal legislation in the last two decades reveals congressional intent to create or expand criminal sanctions in the following areas: insider trading (Insider Trading and Securities Fraud Enforcement Act of 1988, Pub. L. No. 100-704, 102 Stat. 4677 (codified as amended in scattered subsections of 15 U.S.C. $\S 78$ and at $\S 80 \mathrm{~b}-4 \mathrm{a}$ (1988 \& Supp. I 1989)); Insider Trading Sanctions Act of 1984, Pub. L. No. 98-376, 98 Stat. 1264 (codified as amended in various subsections of 15 U.S.C. $\$ 78$ (1988 \& Supp. I 1989))); governinental integrity (Anti-Kickback Act of 1986, Pub. L. No. 99-634, 100 Stat. 3523 (codified at 41 U.S.C. $\$ \S 51-58$ (1988))); environmental protection (Toxic Substances Control Act, Pub. L. No. 94-469, 90 Stat. 2003 (1976) (codified at 15 U.S.C. $\$ \S 2601-2671$ (1988)); Federal Water Pollution Control Act Amendments of 1972, Pub. L. 
Questions abound concerning this use of the criminal law, ranging from the effect such criminal statutes have on the willingness of business enterprises to engage in legitimate ventures ${ }^{2}$ to whether criminalizing commercial behavior reduces the stigma of all criminal convictions. ${ }^{3}$ Those who pose these questions often look for answers within the realm of a certain discipline-economics, for example-or by reference to the juris-

No. 92-500, 86 Stat. 816 (codified as amended at 33 U.S.C. $\$ \S 1251-1387$ (1988 \& Supp. I 1989) (also known as the Clean Water Act))); banking and finance (Money Laundering Control Act of 1986, Pub. L. No. 99-570, tit. I, subtit. H, Anti-Drug Abuse Act of 1986, 100 Stat. 3207 (codified as amended at 12 U.S.C. $\$ 3403$ (c) (1988) and scattered sections of 18 U.S.C. and 31 U.S.C.)); Bank Secrecy Act, Pub. L. No. 91-508, tit. I, II, Bank Records and Foreign Transactions Act, 84 Stat. 1114 (1970) (codified as amended at 12 U.S.C. $\$ \S 1730 d, 1829$ b, 1951-1959 (1988 \& Supp. I 1989), and 31 U.S.C. $\S \S 321,5311-5324$ (1988 \& Supp. I 1989))); communications and information access (Computer Fraud and Abuse Act of 1986, Pub. L. No. 99-474, 100 Stat. 1213 (codified as amended at 18 U.S.C. $\S 1030$ (1988 \& Supp. I 1989)); Cable Communications Policy Act of 1984, Pub. L. No. 98-549, 98 Stat. 2779 (codified as amended in scattered sections of 15 U.S.C., 18 U.S.C., 47 U.S.C., 50 U.S.C.); Counterfeit Access Device and Computer Fraud and Abuse Act of 1984, Pub. L. No. 98473, tit. II, ch. 21, 98 Stat. 2190 (codified as amended at 18 U.S.C. $\$ 1030$ (1988 \& Supp. I 1989))).

In addition, the statutes of some of the more populous states reveal a similar reliance on criminal taw to regulate commercial and financial activity. For example, in 1984 New York imcreased criminal penalties for air pollution. See N.X. ENVTL. ConSERv. LaW $\S \S 71-2105,2113$ (McKinney 1990). Similarly, California recently increased its criminal penalties for insider trading. See CAL. CORP. CODE $\S 25541$ (West 1988 \& Supp. 1991).

2. Scholars have noted the "chilling effect" penal statutes have on legitimate behavior when the standards articulated are vague or general. See, e.g., Ehrlich \& Posner, An Economic Analysis of Legal Rulemaking, 3 J. LEGAL STUD. 257, 263 (1974). Insider trading sanctions and bank secrecy laws have been criticized for the strain they place on legitimate financial behavior. For example, Professor Garten has noted that "[ $t]$ here is a great danger that broad restrictions on insider trading will deter not only misuse of corporate information by some professionals, but also legitimate use of information by other professionals." Garten, Insider Trading in the Corporate Interest, 1987 Wis. L. REv. 573, 577; see also O'Connor, Toward a More Efficient Deterrence of Insider Trading: The Repeal of Section 16(b), 58 ForDHAM L. Rev. 309 (1989) (insider trading regulations promote inefficiency). Professor Villa has argned that the bank secrecy laws as presently constructed deter legitimate bank activity. See Villa, A Critical View of Bank Secrecy Act Enforcement and the Money Laundering Statutes, 37 CATH. U.L. REV. 489, $501-02$ (1988).

3. For example, in reflecting upon corporate criminal liability one scholar has noted that [m]aking morally neutral behavior criminal can undermine the utilitarian goal of prevention in several ways. It may dilute the stigmatizing impact of the criminal law by trivializing it. The severity of the criminal sanction may require that we apply it only to behavior that we are willing to punish by a significant deprivation of liberty. Thus, moral culpability may be required if the legal system is to retain the appearance of fairness necessary to secure the continued support of the law-abiding and to provide the guidance appropriate in a democratic society. Making behavior criminal which is already generally regarded as morally blameworthy will help ensure public support for imposing sanctions with the certainty and severity necessary for meaningful deterrence.

Metzger, Corporate Criminal Liability for Defective Products: Policies, Problems, and Prospects, 73 GEo. L.J. 1, 11 (1984) (footnotes omitted). Packer agrees that as more behavior becomes subject to criminal sanction, less stigma is attached to criminal penalties. See H. PACKER, THE LIMrTS OF THE Criminal Sanction 273 (1968).

The same idea has been discussed in the environmental control arca. One scholar has listed several reasons why criminal penalties are not very effective tools in trying to achieve a eleaner environment, including the reduced stigma attached to a crime that is not morally repugnant (malum in se) but is nonetheless legally prohibited (malum prohibitum). See F. GRAD, TrEaTISE ON ENVIRONMENTAL LAW § 2.08, at 2-555-58 (1984). 
prudence of the criminal law. Most inquiries have been theoretical justifications and objections concentrated on the wisdom of the initial decision to criminalize certain commercial and financial activity. Few, if any, scholars have studied the actual enforcennent of these penal statutes. The absence of such studies is a function, in part, of scholars' interest in the overarching principles of economics, history, and jurisprudence, rather than in the day-to-day enforcement of the law. But we should not ignore the study of the enforcement of existing criminal provisions as we inake decisions about what conduct to criminalize. By examining enforcement of these increasingly popular laws, we can see problems that will confront courts and prosecutors when such penal statutes are created.

This Article will urge caution in further attempts to criminalize financial and commercial activity, argning that such criminalization frequently creates nearly insurmountable proof problems for the prosecution. My study of the enforcement of existing criminal statutes reveals that in prosecutions involving financial and commercial activity, courts often unconstitutionally allow the government to obtain convictions without meeting its burden of proof on all necessary elements of the case. $^{4}$ The largely unspoken motivation for this judicial leniency is judges' realization that the government simply did as well as it could given the systenic proof problems it faced. ${ }^{5}$ Thus, the judicial approach adopted is driven by the context of the specific case rather than the governing legal principles. When such an approach is adopted and legal principles are viewed inore as obstacles than as guides to decision, individual rights are endangered. ${ }^{6}$

To illustrate the problems raised by adopting a context-driven

4. This is directly at odds with established constitutional doctrine created by In re Winship, 397 U.S. 358 (1970), which protects the accused under the due process clause "against conviction exccpt upon proof beyond a reasonable doubt of every fact necessary to constitute the crime with which he is charged." Id. at 364. For purposes of this Article, reference to "burden," "burdenshifting," or "burden of proof" all refer to the prosecution's burden of persuasion to establish all necessary facts beyond a reasonable doubt.

5. This idea is not new. For example, Packer concluded that the development of strict liability in the criminal law came from the belief that "the conventional mens rea notion, that the actor must be consciously aware of the factors making his conduct criminal, places so heavy a burden on law enforcement that it is bound to be resisted." Packer, Mens Rea and the Supreme Court, 1962 SUP. CT. REv. 107, 109. Judge Easterbrook lias noted that the complexity of insidertrading laws and their lack of clarity often create within the judiciary the temptation to say something like "I know insider trading when I see it." See Easterbrook, Insider Trading, Secret Agents, Evidentiary Privileges, and the Production of Information, 1981 SUP. CT. REv. 309, 324.

If these scholars are correct and judges do in fact sidestep a thorough analysis of the law as the law's complexity increases, then continuing to apply criminal law to complex financial and commercial beliavior poses real risks to the development of a body of law that can guide as well as punish.

6. For a discussion of the difference betwecn decisions driven by context and those driven by legal principle, see infra note 292. 
approach, I will examine three areas of enforcement-two arising out of federal criminal tax provisions and one out of the federal securities laws. The tax enforcement discussion will focus on the problems involved in using the net-worth method of proof to estabhish unreported income and the concerns caused by the characterization of corporate diversions as personal income. The securities law enforcement discussion will focus on problems courts face in applying definitions relating to insider trading left largely undefined by Congress.

Part I provides a general overview of federal criminal tax prosecutions. Part II examines the net-worth method of proof, both as an accounting concept and as a legal doctrine accepted and himited by the Supreme Court. Lower courts have ignored Supreme Court limitations on use of this method of proof, often in recognition of the difficulty the government would face if it had to follow the course charted by the Supreme Court for net-worth cases. Part III examines the corporatediversion doctrine as an accounting principle and as a legal issue, and again discusses the judiciary's recognition of the difficulty the government has in following Supreme Court limitations on the use of the corporate-diversion doctrine to prove individual income tax due. Part IV examines the proof problems involved im prosecutions for insider trading and other violations of the securities laws. Although the problems presented in the securities context are often more definitional than investigative, courts are driven by context nore than principle in this area as well. Part $V$ discusses the constitutional principles that are ignored when courts permit the government to obtain convictions without sufficient proof. This Part also surveys other recently criminalized areas in which these constitutional infirmities are likely to emerge.

Significant pressure is placed on the American criminal justice systein when complex cominercial behavior is criminalized and the judiciary seeks to reheve this pressure by failing to enforce constitutionally required standards. I conclude that when new criminal statutes are under consideration, we should make certain not to create probleins of proof for prosecutors so difficult that enforcement may require the courts to disregard constitutional protections.

I

Federal Criminal Tax Prosecutions

To understand the impact sophisticated accounting concepts have on the government's burden of proof in criminal tax cases, it is essential first to know the prosecutor's proof obligations. Each tax crime has spe- 
cific codified elements. ${ }^{7}$ To prove the crime of tax evasion, ${ }^{8}$ for example, the prosecution must establish three elements: the existence of a tax deficiency; an affirmative act constituting evasion or attempted evasion of the tax; and willfulness. ${ }^{9}$ As in any criminal prosecution, the government must establish each element of a tax crime beyond a reasonable doubt. ${ }^{10}$ An acquittal should follow from a failure of proof on any one eleinent.

The "tax deficiency" element is particularly important. The government's proof on this element fails if the government alleges taxes were not paid on income that is in fact nontaxable. ${ }^{11}$ An analysis of the cases

7. For example, it is a crime willfully to file a return or other document, signed under the penalties of perjury, that the individual does not beheve to be true and correct as to every material inatter. See 1.R.C. $\$ 7206(1)$ (1988). The elements of this crime are: making and subscribing a false return or other document; providing information that is not materially true and correct; subscribing to the return or other document under the penalties of perjury; and willfulness. See Siravo v. United States, 377 F.2d 469, 472 (1st Cir. 1967); I.R.C. § 7206(1) (1988).

It is also a crime willfully to aid or assist in, or procure, counsel, or advise, the preparation or presentation of a false or fraudulent return or other document to the Internal Revenue Service (IRS). See I.R.C. $\$ 7206(2)$ (1988). The elements of this crime are: willfulness; materiality; the falsity of the return or other document; and aiding or assisting in, or procurmg, counseling, or advising, the preparation or presentation of a return, affidavit, clain,, or docunient. See id.; see also United States v. Wolfson, 573 F.2d 216, 224-25 (5th Cir. 1978) (knowingly providing an excessively high estinuate of the value of a tax-deductible charitable contribution is sufficient to constitute "aid" under I.R.C. $\S 7206(2)$ ); United States v. Crum, 529 F.2d 1380, 1382 (9th Cir. 1976) (I.R.C. $§ 7206(2)$ covers more than merely the preparers of false returns and apphes to a defendant who backdated purchase contracts).

It is also a crinie willfully to fail to file a tax return. See I.R.C. $\$ 7203$ (1988). The eleinents of this crime as codified are: a duty to file a return for the year charged; failure to file such return at the time required by law; and willfulness. See id.; see also United States v. Fowler, 605 F.2d 181 (5th Cir. 1979) (criminal nature of the intentional failure to file tax return), cert. denied, 445 U.S. 950 (1980).

8. Tax evasion is defined as the "willful[] attempt[] in any manner to evade or defeat any tax imposed . . . or the payment thereof." I.R.C. $\S 7201$ (1988). Tax evasion is a felony. See id.

9. Id.; see also Sansone v. United States, 380 U.S. 343, 351 (1965).

10. For a discussion of what constitutional requireinents are placed on the government in carrying its burden of proof and how these requirenents are routinely ignored by courts in cases dealing with the criminal enforcement of the Internal Revenue Code, see infra notes 36-130 and accoinpanying text.

11. For example, if the receipts alleged to have eseaped taxation are from a loan, there is no tax deficiency because a loan is usually not taxable as incone. Funds received from borrowing are not income, see I.R.C. $\S 61$ (1988), so long as the loan is bona fide, meaning that there is an intent to repay the amount borrowed to the lender. See In re Diversified Brokers Co., 487 F.2d 355, 358 (8th Cir. 1973) (holding that loans are not part of a corporation's taxable income); see also United States v. Pomponio, 429 U.S. 10, 13 (1976) (holding that knowledge that a loan was not bona fide is required for proving evasion of taxes due upon its receipt); United States v. Swallow, 511 F.2d 514, 519 (10th Cir.) (holding that loans obtained in bad faith and without an intention to repay are inconie), cert. denied, 423 U.S. 845 (1975). Similarly, it is a defense to the crime of tax evasion that a defendant can show that she is entitled to additional deductions that would offset the increase in taxable income resulting from the inclusion of previously unreported income. See Willingham v. United States, 289 F.2d 283, 287-88 (5th Cir.) (holding that proving alleged income to be offset by a carry-back loss is a defense to a charge of tax evasion), cert. denied, 368 U.S. 828 (1961).

The government's case will fail in the loan and offsetting deduction instances because the sixteenth amendinent to the Constitution is a limited grant of taxation power that extends to 
in both the net-worth and corporate-diversion areas shows, however, that the government often is permitted to prevail even when it does not estabhish a tax due. ${ }^{12}$ We shall see that the government's failure to prove a tax deficiency is tolerated because of the difficulty in proof and that such failure is disguised behind subtle and unconstitutional burden-shifting devices created by the courts.

II

\section{The Net-Worth METhod of Establishing TAX DEFICIENCIES}

Part of the legacy of the prohibition era was the federal governinent's developinent of the net-worth accounting inethod to prove unreported taxable incoine. ${ }^{13}$ The net-worth method is particularly wellsuited to ferreting out hidden income, especially income from illegal sources. $^{14}$ The method gained fame in the prosecution of notorious

Congress only the power to tax income. See U.S. CONST. amend. XVI; Eisner v. Macomber, 252 U.S. 189, 206 (1920) (holding that the sixteenth amendment applies to income only and "shall not be extended by loose construction"). Therefore, when it has the burden of proof, the government must do more than prove the receipt of funds: it must establish that receipt of the funds resulted both in income and that no taxes were paid on that income.

12. The requirement that a tax deficiency be estabhished is not motivated by a desire to fill the government's coffers: criminal tax cases are not tax collection cases. The purpose of having criminal tax penalties is not to raise revenue (at least not directly) but to punish wrongdoers and deter others from violating the tax laws. To facilitate enforcement, judicial standards have been loosened. For example, even though a tax deficiency has to be established in tax-evasion prosecutions, courts have held that the government is not required to establish an exact amount. Rather, to carry its burden the government simply must show a substantial-as opposed to an exact-tax deficiency. See United States v. Burkhart, 501 F.2d 993, 995 (6th Cir. 1974), cert. denied, 420 U.S. 946 (1975); Canaday v. Umited States, 354 F.2d 849, 851-52 (8th Cir. 1966). A "substantial" deficiency can be a relatively small amount of money. For instance, a substantial tax deficiency has been found in a case in which the government established an additional tax owed of only \$3358.68. See United States v. Davenport, 824 F.2d 1511, 1516-17 (7th Cir. 1987). In another case, tax deficiencies of $\$ 3956.29$, $\$ 900.14$, and $\$ 2209.48$ were all held to be substantial. See United States v. Siragusa, 450 F.2d 592, 595-96 (2d Cir. 1971), cert. denied, 405 U.S. 974 (1972).

13. As noted by one scholar:

In the victorious aftermath of World War 1 , the economy of the United States was growing by "leaps and bounds." . . . Big noney and high living were the order of the day for grafters, gamblers, gangsters, bootleggers, hijackers, slick operators, and ordinary citizens caught up in the Jack-in-the-Beanstalk economy of the period. The bootleggers and hijackers were the aristocracy of the underworld. There is scant information available regarding early criminal tax cases; however, it is clear from literature covering the period and from public statements inade by IRS representatives, that throughout the $1920 \mathrm{~s}$ and 1930s taxpayers who were perceived by the IRS as being engaged in illicit incomeproducing activities received special attention from IRS criminal investigators.

1 D. McGowen, D. O’Day \& K. North, Criminal and Civil Tax Fraud $\S 1.01$, at 2-3 (1986) (citations omitted); see also Holland v. United States, 348 U.S. 121, 126 (1954) (explaining basic assuniptions of the net-worth nethod).

14. This is true because the inethod does not depend on proof of specific income items. When the net-worth method is used, the inference that income was received flows from a comparison of a defendant's worth to her reported taxable income. Therefore, if the government has no specific proof that a defendant received income fron gambling or bootlegging, it can resort to the net-worth 
crime figures such as the Capones ${ }^{15}$ and is still a vital part of federal prosecutions involving narcotics trafficking and other illicit activity. ${ }^{16}$

While enormously valuable, the use of the net-worth inethod is not without probleins. ${ }^{17}$ Before examining such problems, it is important to understand what the method does and how it does it. The net-worth method is an indirect method of proving the receipt of taxable incoine. ${ }^{18}$ It allows the government to prove taxable incoine without a cancelled check, a bank account deposit ship, testimony, or any other specific evidence. Under the net-worth method, the conclusion of taxable income flows froin certain accounting inferences, ${ }^{19}$ and the government uses this

method to prove its tax evasion allegation. The net-worth method is "a potent weapon in establishing taxable income from undisclosed sources when all other efforts fail[]." Holland, 348 U.S. at 126. For a discussion of this method of proof, see infra notes 18-23 and accompanying text.

15. The net-worth method was first used in such cases as Capone v. Urited States, 51 F.2d 609 (7th Cir.), cert. denied, 284 U.S. 669 (1931), and Guzik v. United States, 54 F.2d 618 (7th Cir. 1931), cert. denied, 285 U.S. 545 (1932). See Holland, 348 U.S. at 126. The Capone in the cited case is Ralph "Bottles" Capone, the older brother of Al Capone; Jack Guzik was the number three man in Al Capone's Chicago organization. See Comisky, The Likely Source: An Unexplored Weakness in the Net Worth Method of Proof, 36 U. Miami L. REv. 1, 3 n.6 (1981).

In addition to cracking the untouchable Capone organization, the IRS was also involved with other high-profile crime fighting, including the imvestigation of the Lindbergh kidnapping, the crackdown on Huey Long and the Pendergast organization, and the conviction of Irving Wexler, a.k.a. Waxie Gordon. See United States v. Wexler, 79 F.2d 526 (2d Cir. 1935), cert. denied, 297 U.S. 703 (1936); A. HyNd, The Giant Killers 12-13 (1945).

16. See, e.g., United States v. Caswell, 825 F.2d 1228 (8th Cir. 1987) (unreported income from gambling); United States v. Chu, 779 F.2d 356 (7th Cir. 1985) (unreported income from selling a controlled substance); Umited States v. Gomez-Soto, 723 F.2d 649 (9th Cir.) (unreported income from sellimg cocaine), cert. denied, 466 U.S. 977 (1984); United States v. Thetford, 676 F.2d 170 (5th Cir. 1982) (unreported income from pornographic inovie theaters), cert. denied, 459 U.S. 1148 (1983); United States v. Giacalone, 574 F.2d 328 (6th Cir.) (unreported income from gambling), cert. denied, 439 U.S. 834 (1978); Umited States v. Costello, 221 F.2d 668 (2d Cir. 1955) (unreported income from gambling), aff'd, 350 U.S. 359 (1956).

17. As noted by the Supreme Court, the net-worth method of proof "has evolved from the final volley to the first shot in the Government's battle for revenue, and its use in the ordinary incomebracket cases greatly increases the chances for error." Holland v. United States, 348 U.S. 121, 12627 (1954).

18. See United States v. Terrell, 754 F.2d 1139, 1144-45 (5th Cir.), cert. denied, 472 U.S. 1029 (1985) (government uses this inethod when it has to reconstruct imcome because a taxpayer's records are madequate or income has been concealed). For a discussion of the indirect nature of the networth method, see 1 D. MCGowen, D. O'DAY \& K. NORTH, supra note 13, \$§ 23.14-.40, at 817 70.

19. These inferences are inore than the typical inferences that flow from circumstantial evidence. The Supreme Court's awareness of the unique nature of the net-worth method's use of circumstantial evidence bears repeating in detail. The Court concluded that the method

involved something inore than the ordinary use of circumstantial evidence in the usual criminal case. Its bearing, therefore, on the safeguards traditionally provided in the administration of criminal justice called for a consideration of the entire theory. At our last Term a number of cases arising from the Courts of Appeals brought to our attention the serious doubts of those courts regarding the implicatious of the net worth method. Accordingly, we granted certiorari in these four cases ....

....

... [C]areful study indicates that [the net-worth method] is so fraught with danger for the innocent that the courts must closely scrutinize its use. 
indirect method to meet its burden on the first element of the crime of tax evasion by showing a tax deficiency. Often, a failure of the net-worth method means that the government cannot prove the deficiency element, and therefore an acquittal should be entered.

Simply put, under the net-worth method the government contrasts the amount a defendant owes with the amount she owns, looks at reported taxable mcome during the period in question, and concludes from these data whether the defendant failed to report taxable income. ${ }^{20}$ For example, assume that in $1986 X$ had a reported taxable income of $\$ 30,000$ on which she paid all taxes. Assume as well that at year end $X$ owned a car, which she purchased for $\$ 7000$, and had $\$ 3000$ in savings. Assuming $X$ had no other assets, her asset total at year-end 1986 was $\$ 10,000 .^{21}$ Assume also that $X$ had a car note of $\$ 4000$ and debts on credit cards totaling $\$ 2000$. Therefore, at the end of $1986 X$ had a net worth of $\$ 4000$ ( $\$ 10,000$ in assets minus $\$ 6000$ in habilities).

Assume further that in $1987 X$ again reported $\$ 30,000$ in taxable mcome. However, during this year she purchased a $\$ 100,000$ home with a $\$ 50,000$ down payment, bought a new car outright for $\$ 20,000$, paid off all her credit card debts, and paid the note on her previous car, which she traded in at the time that she purchased the new car. Therefore, at the

\section{Holland, 348 U.S. at 124-25.}

20. As the Supreme Court stated in Holland:

In a typical net-worth prosecution, the Government, having concluded that the taxpayer's records are inadequate as a basis for determining income tax liability, attempts to establish an "opening net worth" or total net value of the taxpayer's assets at the beginning of a given year. It then proves increases in the taxpayer's net worth for each succeeding year during the period under examination and calculates the difference between the adjusted net values of the taxpayer's assets at the beginning and end of each of the years involved. ... [I]f the resulting figure for any year is substantially greater than the taxable income reported by the taxpayer for that year, the Government clains the excess represents unreported taxable income.

Holland, 348 U.S. at 125.

21. In a typical net-worth case assets are measured at cost and appreciation in value is not considered. If the appreciated value of an asset were included on a net-worth schedule, the government could demonstrate, using the net-worth method of proof, that taxpayers holding appreciating assets such as homes have unreported income. However, because the government uses the net-worth method to discover income rcceived rather than increases in value, assets are listed at cost and most taxpayers are safe from IRS scrutiny. See generally 1 D. MCGowEN, D. O'DAY \& K. NoRTH, supra note $13, \S 23.14$, at $817-18$ (discussing how net worth is calculated).

In some isolated instances, cost should not be used to measure the asset. If the taxpayer rcceives a gift, it is more accurate to measure the asset by the basis of the gift in the hands of the donor rather than at cost. For example, assume taxpayer $X$ receives as a gift in year one a necklace with a basis of $\$ 10,000$ in the donor's hands and a fair market value of $\$ 10,000$. Assume $X$ holds the necklace for four years and then in year five sells the necklace for $\$ 10,000$ and purchases a car with the proceeds. If the necklace and the ear were measured at cost in determining net worth, the sale of the necklacc and subsequent purchase of the ear would lead one to the inaccurate conclusion that $X$ in year five had a net-worth increase of $\$ 10,000$ for purposes of criminal tax prosecution. For a discassion of the tax concept of basis, see infra notes 111 and 115 and accompanying text. 
end of $1987 X$ 's net worth was $\$ 70,000(\$ 120,000$ in assets (the home and the car) minus $\$ 50,000$ in liabilities (the inortgage)).

Froin the data in this example we can see that $X$ 's net worth increased by $\$ 66,000$ froin 1986 to 1987 on a reported taxable incoine of $\$ 30,000$. Even if we assume that $X$ did not spend any money on hiving expenses $^{22}$ and that her entire $\$ 30,000$ incoine went to purchase assets, it is obvious that she soinehow acquired money im excess of her reported income for purchase of these assets. The question in a government tax investigation and prosecution is whetler the extra inoney came froin a currently taxable source or from a nontaxable source. A number of nontaxable sources, such as gifts, loans, inheritances, and savings froin past years, could result in an increase in net worth without any current-year imcome tax consequences. ${ }^{23}$

In this hypothetical example it seems quite easy to prove a tax deficiency through the net-worth inethod. In reality, however, the government must resolve two inajor probleins before it proceeds with a prosecution. First, it inust decide whether to prove that unreported income came from a known, likely incoine source. Second, it inust establish an opening net worth with reasonable certainty. An examination of these issues will provide insights into the coinplexity of the proof in such a prosecution.

\section{A. Identifying a Likely Source of Income}

To understand the importance of the concept of likely source of income, one inust turn to the definitive Supreme Court decision upholding the government's use of the net-wortl method of proof in criminal tax cases. In Holland v. United States ${ }^{24}$ the Supreme Court evaluated the government's use of this indirect inethod, articulated its inherent dangers, and limited its use.

To the Holland Court, one of the most serious flaws in the widespread use of the net-worth method was the assumption "that most assets derive from a taxable source." 25 The Court rejected this assuinption, recognizing that a number of nontaxable sources, such as gifts, can equally

22. In reality, the defendant's nondeductible expenditures, including living expenses, are added to net-worth increases in order to give a more accurate picture of unreported taxable income. Because most living expenses are nondeductible expenditures, the government in this hypothetical could add to the alleged net-worth mcrease the amounts spent by $X$ for such items as electricity, food, and other necessities. See United States v. Carter, 462 F.2d 1252, 1253 (6th Cir.), cert. denied, 409 U.S. 984 (1972).

23. For a discussion of the importancc of negating nontaxable sources of money in order to produce a valid net-worth calculation of taxable income, see infra notes 24-28 and accompanying text.

24. 348 U.S. 121 (1954).

25. Id. at 126 . 
explain an increase in net worth. Realizing, however, that the prosecution inight not be able to negate the existence of all nontaxable sources in every case, the Holland Court permitted a jury to draw the inference that the increase in net worth was attributable to taxable income if the government first established "a likely source, from which the jury could reasonably find that the net worth increases sprang."26 The Court noted, however, that if a defendant provided a nontaxable source of the increase, the proof of a likely imcome source did not excuse the government from investigating all explanations provided by the defendant that were reasonably susceptible of being checked. ${ }^{27}$

In later Supreme Court and courts of appeals decisions this holding in Holland has been interpreted to give the prosecution two options when it proceeds under the net-worth method. First, the government may attempt to establish the existence of a likely source capable of producing the net-worth increase. Successfully estabhishing a likely source allows the jury to infer that the increase came from currently taxable income, provided that the government also negates all reasonably verifiable nontaxable explanations given by the defendant. Second, if the government cannot establish a likely source, it inay instead attempt to negate the possibility that nontaxable sources could have produced the increase. ${ }^{28}$

The limitation on the use of the net-worth method created by Holland and its progeny places serious investigative burdens on the government. For example, in United States v. Blandina ${ }^{29}$ the government argued that the defendant's hquor store was the likely source of the networth increase. ${ }^{30}$ However, the defendant offered two nontaxable sources for his increase in net worth, claiming that he received the money from his father, who had settled an accident claim, and also that he sold his father's coin collection for cash. ${ }^{31}$ As a result, the government was required to negate the existence of these nontaxable sources before the jury could be permitted to infer that the bulge in the net worth came from the hikely, taxable source.

26. Id. at 138 .

27. Id. at 135-36.

28. See, e.g., United States v. Massei, 355 U.S. 595 (1958) (no proof of likely source necessary should all possible nontaxable sources be negatived); United States v. Chu, 779 F.2d 356, 366 (7th Cir. 1985) (government's burden of proof is satisfied if it shows likely source or negatives all possible sources of nontaxable income (citing United States v. Grasso, 629 F.2d 805, 808 (2d Cir. 1980))).

29. 895 F.2d 293 (7th Cir. 1989).

30. Id. at 294. The evidence the government presented to establish likely source was sparse. The government was able to produce no evidence that Blandina's liquor store was capable of generating the amount of income alleged because Blandina refused to allow the governnent to inspect his business records. See id. at 302-03. For a discussion of why it is iniportant that the government prove that the alleged likely source was capable of generating the net-worth increase, see infra notes 38-58 and accompanying text.

31. Blandina, 895 F.2d at 294. 
Investigating defendant-provided leads on nontaxable sources of income can be enormously expensive and time consuming. The governinent investigating agent in Blandina had to check with banks used by the defendant's father, interview family members about the accident settlement, review Internal Revenue Service (IRS) records to determine if the father filed a tax return for the gift of coins to the defendant, check probate records to establish that the coin collection was not listed as an asset, and interview sixty-one coin dealers from three cities in the vicinity of the defendant's hoine in order to determine if any of those dealers had purchased coins froin the defendant. ${ }^{32}$

The investigative burden inultiplies when the government has no likely source and thus inust negate the existence of all possible nontaxable sources that could have contributed to the net-worth increase rather than just those sources claimed by the defendant. In one case, United States v. Mastropieri, ${ }^{33}$ an IRS agent

canvassed 47 banks, 71 brokerage firms and 13 lending institutions in the vicinity .... [He] searched the local property records of Bronx, Nassau, Queens, Kings and Suffolk Counties [for the years 1967 to 1975] ... He checked records of the Savings Bond division of the United States Treasury Department covering [at least the period 1952 through 1975] .... [The agent] checked . . . gift tax returns. He checked County Clerk records to determine whether [the defendants] had received any funds from judgments or inheritances. He also interviewed unnanied friends and relatives of the [defendants] to determine whether they had loaned or given any inoney to $[$ them] ...34

As can be seen in the foregoing exainples, establishing a likely source of incoine as required by the court in Holland can translate into an incredibly complex investigative task in many cases. In soine cases, however, the task is not completed, but the conviction is still obtained and upheld. ${ }^{35}$

32. Id. at 302 .

33. 685 F.2d 776 (2d Cir.), cert. denied, 459 U.S. 945 (1982). The Second Circuit noted in its opinion the confusion about whether the case was prosecuted using the net-worth or the cashexpenditure method of proof. See id. at $778 \mathrm{n} .2$. For this Article's purposes there is no difference betwecn the two methods as both require a likely source of income and an opening net worth calculated with reasonable certainty. For a discussion of the cash- or nondeductible-expenditures method of proof, see 1 D. MCGowEN, D. O'DAY \& K. NORTH, supra note 13, $\S \S 23.35-.40$, at 86770.

34. Mastropieri, 685 F.2d at 779 (footnotes omitted). This effort is all the more extraordinary because the government had an admission from the defendants, made just six months before the opening net-worth year, that they had no assets. Id. However, understanding well its burden, the government in this case did not rely simply on the defendants' admission. It realized that because it could not establish a likely source, its burden required it to negate all "rcasonably possible" nontaxable sources. See id. at 785 . The defendants' admission only established assets held by the defendants; it did not address the source-of-income issue, and therefore the admission was of little value to this aspect of the government's necessary proof.

35. This investigative burden also can be seen in United States v. Scott, 660 F.2d 1145 (7th Cir. 


\section{B. Proof Problems Created by the Likely Source Requirement}

Since the Supreme Court in Holland created the likely source requirement, ${ }^{36}$ federal appellate courts have denonstrated little desire to reverse tax convictions on the grounds that the governinent failed to prove a likely taxable source capable of producing the net-worth increase. ${ }^{37}$ This is true even though the Holland Court clearly linked the sufficiency of the likely source evidence to the government's proof of the financial capacity of the defendants' business. ${ }^{38}$ The Court emphasized that "the disclosed business of the petitioners was proven to be capable of producing inuch more income than was reported and in a quantity sufficient to account for the net worth increases." 39 Furthermore, the Court noted that "the net worth increase claimed by the Government for 1948 could have come entirely froin the unreported income of the hotel and still the hotel's total earnings for the year would have been only $73 \%$ of the suin reported by the previous owner for the coinparable period." 40

The Holland Court intended the likely source requirement to mean soinething more than a possible source of some taxable income. The

1981), cert. denied, 455 U.S. 907 (1982). Scott involved the tax-evasion prosecution of a former Attorney General for the State of Illinois. The government claimed that Scott's likely source for the increase in his net worth was campaign contributions he converted to his own personal use. Id. at 1148. Conversely, Scott argued that the increase in his net worth came from gifts, a nontaxable source. Id. On the eve of indictment, Scott provided the Department of Justice with a list of 100 persons who allegedly made such gifts. Id. at 1157. The government attempted to contact all these individuals, even though it was facing the possibility that the statute of limitations on the first prosecution year would run. The government found that 75 of the alleged donors gave only nominal gifts, 2 did not exist, 16 could not be reached, and 2 would not talk. Only one remembered giving a substantial gift during this period. Id.

36. For a discussion of the likely source requirement articulated in the Holland decision, see supra notes 24-35 and accompanying text.

37. See Comisky, supra note 15 . In this article, Comisky detailed a number of appellate decisions issued after the Supreme Court's announcement of its ruling in Holland. See id, at 12-16. From this analysis Comisky concluded that the lower courts often ignore Holland's likely source requirement and, in so doing, shift the burden unconstitutionally to the defendant. Id. at 30 . Cases cited by Comisky for this proposition included: United States v. Hamilton, 620 F.2d 712 (9th Cir. 1980) (finding proof of defendant casino manager's unusual system of handling slot machine revenue sufficient for conviction without evidence that defendant skimmed from receipts or that amount skimmed could account for net-worth increase); Whitfield v. United States, 383 F.2d 142 (9th Cir. 1967) (affirming conviction based upon government's establishing a motel as likely source without proof of inotel's capacity to generate net-worth increase); United States v. Ford, 237 F.2d 57 (2d Cir. 1956) (affirming prosecution based upon opportunity of police officer to take bribes as likely source without proof of amount or nature of bribes), vacated as moot, 355 U.S. 38 (1957); United States v. Adonis, 221 F.2d 717 (3d Cir. 1955) (affirming conviction despite no proof that likely source was capable of generating net-worth increase); United States v. Costello, 221 F.2d 668 (2d Cir. 1955) (affirming conviction on the ground that likely source-gambling-had indeterminate possibilities for producing income, despite absence of proof as to its actual capacity to generate alleged net-worth increase), aff'd, 350 U.S. 359 (1956).

38. See Holland v. United States, 348 U.S. 121, 137-38 (1954).

$39 . \quad$ Id. at 138.

40. Id. at 137. 
Court required first that the likely source be linked directly to the defendant, usually through ownership. Next, the Holland Court required an investigation of the source's capacity to generate income. Lastly, the Holland Court required a demonstration that the likely source could generate sufficient mcome to explain the net-worth increase. ${ }^{41}$ The Holland Court found that in the case before it the government had provided such proof, and therefore carried its burden on likely source.

United States v. Grasso ${ }^{42}$ shows this same careful approach. The Second Circuit reversed the defendant's conviction even though the defendant owned several businesses from which the alleged unreported taxable income could have come. ${ }^{43}$ The court concluded that the government's proof on likely source was insufficient because the government had "made no effort to ascertam whether the ainounts [the defendant] reported as having received from those [likely] sources were understated." 44 According to the court, without proof that the sources were capable of generating income above the ainounts defendant had previously reported, the evidence of likely source was inadequate. ${ }^{45}$ Consequently, reversal was mandated.

Unfortunately, the Grasso analysis is not representative of other appellate decisions. ${ }^{46}$ In United States v. Gomez-Soto, ${ }^{47}$ for example, the defendant, who was accused of importing cocaine, argued that the government had not established that the assets of certain Colombian corporations attributed to him actually belonged to him. ${ }^{48}$ The Ninth Circuit responded to this contention with an unsatisfying non sequitur, stating that the government only had to "identify" a likely source and that once this was done, "[t]he government is not required 'to embark on a Magel-

41. Usually the prosecution in a net-worth case is sensitive to the need to establish a likely source capable of generating the net-worth increase. For example, suppose the government establishes that a defendant is employed by a dress shop and earns a yearly salary of $\$ 25,000$. Suppose further that for the prosecution period of three years, the net-worth increase is over $\$ 200,000$. If the government were to argue that the source of this net-worth increase was the salary from the dress shop, a jury probably would not accept that explanation.

Cases involving more serious allegations of wrongdoing-such as gambling, selling drugs, loan sharking, accepting bribes, and skimming receipts-are more troublesome. In these situations, the jury is more likely to ignore shortcomings in the prosecution's case, and the government is thus much less concerued with the possible jury reaction to its failure to establish the income-producing capacity of the likely source.

42. 629 F.2d 805 (2d Cir. 1980).

43. Id. at 808 .

44. Id.

45. Id.

46. For a discussion of other appellate cases that fail to analyze this issue in the same thoughtful way as the Grasso court, see supra note 37 and accompanying text.

47. 723 F.2d 649 (9th Cir.), cert. denied, 466 U.S. 977 (1984).

48. Id. at 655 . 
lan-hike expedition in order to prove that the unreported income was taxable." "49 The court never answered the defendant's complaint that ownership was not established and devoted no attention to whether the Colombian businesses could have generated income sufficient to account for the increase in net worth. ${ }^{50}$

To avoid the Holland requirement that the government prove the identified source capable of producing the net-worth increase, many courts lrave made use of the concept of "indeterminate possibilities." In situations imvolving graft, ${ }^{51}$ gambling, ${ }^{52}$ or skimming from corporate funds ${ }^{53}$ courts have upheld convictions if the government has sliown that the imcome-producing source could generally generate large amounts of income. Such courts have required no showing that the specific source in question could at the present time generate the requisite income or even that it liad ever done so in the past. In United States v. Costello, ${ }^{54}$ for example, the government established that the likely source of defendant's increase in net wortll was winnings from gambling. The court opined that because gambling had "indeterminate possibihities" for generating income, the government, contrary to the lolding in Holland, did not have to prove that the defendant's gambling was capable of generating taxable income of the particular amount necessary to account for the networth mcreases. ${ }^{55}$ Such a permissive attitude allows the government to convict witlout satisfying its burden of proof. The constitutional requirements of Holland and In re Winship ${ }^{56}$ were thus summarily ignored.

49. Id. (quoting United States v. Hamilton, 620 F.2d 712, 714 (9th Cir. 1980)).

50. The defendant in Gomez-Soto allegedly was importing cocaine. This may have contributed to the court's inclination to affirm the conviction even though the government did not have sufficient evidence of likely source. Typically in large drug prosecutions, the government will add tax-evasion counts to the charges against a defendant and will use the net-worth method of proof to establish the evasion. In these cases the government will allege that the likely source is drug selling and will rely on the amount and street value of the drugs sold to establish the income-producing capacity of the source. Even when the drug prosecution does not involve amounts large enough to explain the networth increase, the prosecution in such cases may not be particularly concerned. If the drug charge is established, the jury will likely assume that the net-worth increase came from drug selling; further, appellate courts typically affirm convictions based on this assumption. For a discussion of a jury's reaction to likely source proof in such cases, see supra note 41.

51. See, e.g., United States v. Ford, 237 F.2d 57 (2d Cir. 1956) (tax-evasion prosecution of vice squad polieeman who allegedly was accepting bribes), vacated as moot, 355 U.S. 38 (1957).

52. See, e.g., United States v. Costello, 221 F.2d 668 (2d Cir. 1955) (tax-evasion prosecution of man who allegedly rcceived undisclosed incoine from bets on horses, cards, and fights), aff'd, 350 U.S. 359 (1956).

53. See, e.g., United States v. Haniliton, 620 F.2d 712 (9th Cir. 1980) (tax-evasion prosecution of casino manager accused of skimming funds); United States v. Maekey, 345 F.2d 499 (7th Cir.) (tax-evasion prosecution of man who einbezzled inoney froin three companies he owned), cert. denied. 382 U.S. 824 (1965).

54. 221 F.2d 668 (2d Cir. 1955), aff'd, 350 U.S. 359 (1956).

55. Id. at 672 .

56. 397 U.S. 358 (1970); see supra note 4. 
The courts' actions, however, were not motivated by a whimsical desire to disregard the Constitution but rather by an understanding of the near-impossible task prosecutors face. Prosecutors must, under Holland, prove a likely source of sufficient income-producing capacity. The capacity of certain likely sources, such as gambling, is not, however, easily discoverable, nor is the source's financial history. Moreover, the government in many of these cases has expended extraordinary effort in conducting as thorough an investigation as possible. ${ }^{57}$ Such thoroughness would impress any appellate court and almost certainly encourages courts to wink at a strict apphication of the likely source requirement, especially when the financial capacity of the source is not easily discoverable. ${ }^{58}$

\section{Establishing an Opening Net Worth}

The second requirement the government must meet in any prosecution using the net-worth method is the estabhishment of an opening net worth. The net-worth method entails the government's determining the increase over a period of time in the defendant's assets and comparing this increase to the defendant's reported taxable income for the same period. The beginning point of the comparison is therefore of vital importance in establishing an increase in net worth.

In tax evasion prosecutions, the opening net worth is the defendant's net worth on the last day of the tax year immediately preceding the first prosecution year. The Supreme Court confirmed in Holland that establishment of this opening net worth with reasonable certainty was essential to a tax prosecution based on the net-worth method..$^{59}$ The Court noted that "[t]he importance of accuracy in this figure is immediately apparent, as the correctness of the result depends entirely upon the inclusion in this sum of all assets on hand at the outset." $" 60$

A simple illustration establishes the truth of the Court's statement.

57. For examples of the government's investigative effort to confirm the net-worth analysis, see supra notes 29-35 and infra notes 67, 72-78 and accompanying text.

58. Of course, the government can always attempt to negate all nontaxable sources of income that could have caused the net-worth increase. In practice, even when it has a likely source, the prosecution often attempts to regate nontaxable sources in order to bolster its case before the jury or to guard against dismissal should the likely source evidence prove insufficient.

However, several IRS special agents have mdicated to me in private discussions that the investigation of a net-worth case is not as extensive today as it was in the past, in part because of the decreased emphasis on negating noutaxable sources. The lenient judicial approach to the enforcement of the Holland standards and other constitutional principles, see infra notes 234-67 and accompanying text, might be a factor in deereasing the amount of attention the IRS gives to such cases. This decreased level of attention only exacerbates the problems discussed here.

59. Holland v. United States, 348 U.S. 121, 132 (1954).

60. Id. 
Returning to the hypothetical discussed earher ${ }^{61}$ in which $X$ increased her net worth by $\$ 66,000$, suppose that the government failed to include $\$ 65,000$ in stocks in $X$ 's opening net worth for 1986 . Had this asset been included, the government would have determined $X$ 's net worth to be $\$ 69,000$ rather than $\$ 4000$. Not including the stocks in the net-worth calculation of course affects the government's subsequent conclusions. Recall that in the hypothetical the governinent determined that $X$ 's net worth increased $\$ 66,000$ in 1987 . If, however, the opening net worth figure with the added stock asset were used, $X$ 's net-worth increase in 1987 would only have been $\$ 1000 .^{62}$ The $\$ 66,000$ increase would be accurate if $X$ continued to hold the stocks in 1987 and still made the additional acquisitions. ${ }^{63}$ However, if $X$ sold these stocks in 1987-perhaps to finance her home and car purchase-the $\$ 66,000$ net-worth increase would be reduced to $\$ 1000$. The failure to include one asset can therefore skew an entire net-worth analysis; such a failure has led to the reversal of convictions in several cases. ${ }^{64}$

In practice, however, estabhishing with reasonable certainty an opening net worth that includes all of the defendant's assets involves a serious investigative commitment. Assets inust be discovered ${ }^{65}$ and their continued ownership by the defendant traced to establish whether their sale financed the acquisition of other assets. ${ }^{66}$ Because such investigations must be performed within the confines of certain constitutional protec-

61. See supra notes $20-23$ and accompanying text.

62. The $\$ 70,000$ net worth for 1987 minus $\$ 69,000$, the recalculated net-worth figure for 1986 (assuming, of course, that the $\$ 70,000$ net-worth figure is not affected).

63. If $X$ held the stocks through 1987, her net-worth figure for that year would also be understated by $\$ 65,000$, and thus the net-worth increase would remain $\$ 66,000$ ( $\$ 135,000$ minus $\$ 69,000)$.

64. See United States v. Keller, 523 F.2d 1009, 1011 (9th Cir. 1975) (reversing conviction because opening net-worth calculation was not "reasonably certain"); Merritt v. United States, 327 F.2d 820, 821-22 (5th Cir. 1964) (reversing conviction because government's agent admitted knowledge of assets owned by defendant that were not included in opening net-worth figure); United States v. Achilli, 234 F.2d 797, 804 (7th Cir. 1956), aff'd, 353 U.S. 373 (1957) (reversing conviction because government did not include in its opening net-worth estimate an asset that accounted for $80 \%$ of alleged tax deficiency claimed).

65. For a discussion of the investigative burdens involved in tracking down possible sources of income, see supra notes 29-35 and accompanying text.

66. See 1 D. McGowen, D. O'DAY \& K. NORTH, supra note $13, \S 23.22$, at 837-38, § 23.23, at 843-44. Some argue that assets owned by a defendant throughout the prosecution period need not be listed on the net-worth schedule because such assets could not have contributed to the net-worth increase. At times, however, the exclusion of such assets will be misleading. For example, if a defendant has $\$ 1,000,000$ in assets that are owned throughout the period and all such assets are excluded from the net-worth schedule, and if the remaining listed assets on the schedule total only $\$ 100,000$, then a $\$ 50,000$ increase in net worth looks large in comparison to the listed assets of $\$ 100,000$. The same increase would look quite small when compared to total assets of $\$ 1,000,000$. A jury might find it unlikely that a defendant was not aware of a $\$ 50,000$ increase in net worth when other assets are only $\$ 100,000$, but might believe that a defendant with assets of $\$ 1,000,000$ was unaware of his $\$ 50,000$ increase in worth. 
tions that prohibit compelled disclosure from a defendant, the investigations can take three or four years. ${ }^{67}$

Cash on hand is often the most difficult opening net-worth item to calculate with reasonable certainty. "Cash on hand" refers to all hquid assets not deposited in a bank or other financial institution. ${ }^{68}$ Thus, the term embraces only inoney carried on the person of the defendant, kept in a safe or safety deposit box, or, perhaps, buried in the backyard.

Why is it important for the government to establish the amount of cash on hand? Cash accumulated in prior years is taxable only in the year earned. ${ }^{69}$ Acquiring assets in a subsequent year by spending cash accuinulated in prior years will mcrease net worth without any currentyear tax consequences. The government must, therefore, determme the atnount of cash on hand at the starting point to estabhsh that the increase in net worth is from a source taxable in the prosecution year and not from the spending of cash accumulated in prior years. Because cash accumulations are difficult to trace, defendants often argue that their increase in net worth came from cash saved from prior years that they kept liquid rather than investing or depositing. ${ }^{70}$

Defendants can offer a variety of explanations for the accumulation, including savings from many years, gifts, inheritances, and gambling winnings. In Holland, for example, the defendants argued that the

67. See United States v. Terrell, 754 F.2d 1139, 1147 (5th Cir.), cert. denied, 472 U.S. 1029 (1985) (describing a three-and-one-half-year investigation); United States v. Schafer, 580 F.2d 774, 777 (5th Cir.) (describing a four-year investigation), cert. denied, 439 U.S. 970 (1978).

68. Bank balances are not included in the definition of cash on hand and are usually carried as an asset on the net-worth schedule. See 1 D. MCGOwEN, D. O'DAY \& K. Nor'TH, supra note 13, $\S 23.24$, at 846 .

69. See United States v. Boulet, 577 F.2d 1165, 1167-68 (5th Cir. 1978) (because the "income tax system is on an annual basis, failure to report income inust be charged for a specific year"), cert. denied, 439 U.S. 1114 (1979); Commissioner v. Frame, 195 F.2d 166, 166 (3d Cir. 1952) (income from prior years cannot be taxed in current year, even if it was unreported in previous years). Defendants who clain their cash on hand came froin prior-year savings should expect to see government proof that they could not have saved inoney from this earlier period given the amount of taxable income reported for those years. This kind of analysis is called a "source and application of funds" analysis. See infra note 75 for a further discussion of this method of proof. If this proof is convincing, and it usually is, the defendant will have to counter the inference logically available to the jury that any savings in prior years actually came from tax evasion on unreported income. It is likely that the jury will conclude from this prior-year evidence that the defendant is indeed a "tax evader." Defense lawyers are aware that defending a net-worth analysis by claining cash accumulations came from savings is often a double-edged sword. See 1 D. MCGowEN, D. O'DAY \& K. NoRTH, supra note $13, \S 23.24$, at 849 .

70. See, e.g., Holland v. United States, 348 U.S. 121, 132-34 (1954) (defendant claimed accumulation of $\$ 113,000$ in currency and hundreds of shares of stock); United States v. Blandina, 895 F.2d 293, 301-02 (7th Cir. 1989) (defendant claimed cash hoard accumulated through sale of father's coin collection and proceeds of accident settlement received from father); United States $v$. Chu, 779 F.2d 356, 362-64 (7th Cir. 1985) (defendant claimed he made a practice of keeping large amounts of cash on hand); United States v. Bethea, 537 F.2d 1187, 1190 (4th Cir. 1976) (defendant claimed that cash hoard had been buried in backyard). 
increase in net worth for 1948, the prosecution year, came from a preexisting cash hoard of $\$ 113,000$ that they had accumulated froin 1933 to $1945 .^{71}$ To establish that the defendants' cash on hand was significantly less than the amount claimed, the government proved that the defendants had endured "hardship and privation"72 during the period when the cash accumulation allegedly occurred. The government pointed out that during the period from 1933 to 1945, the defendants lost their business, had their household furniture repossessed (due to an unpaid balance of less than $\$ 100$ ), and endured an economically related family separation of eight years. ${ }^{73}$ The government used this evidence to support the inference that no one would undergo such suffering if in fact they possessed cash savings of the magnitude claimed. However, to establish this history of financial despair, the government had to research the defendants' financial history back to the $1920 \mathrm{~s}^{74}$ Although this thoroughness convinced the jury and the Supreine Court that the fignre for cash on hand was well below the anount claimed, such intensive investigation is not easily performed in all cases.

In many net-worth cases the government establishes the amount of cash on hand to be neghigible by proving that a defendant could not have accumulated excess funds froin previous years in any appreciable quantity. ${ }^{75}$ This use of "source and application of funds" analysis also requires painstaking investigation involving a great deal of time, energy, and employee effort. For example, in United States $v$. Terrell ${ }^{76}$ the court noted that the

investigation consumed three and one-half years. Approximately 20 agents canvassed public records to determine the extent of appellant's holdings. Thirty banks were contacted, and twenty banks produced documents or witnesses. Nearly 300 potential witnesses were interviewed, many of them several times. IRS agents identified in excess of 70 assets purchased and sold by [the defendant], and questioned third parties involved in these transactions. Additionally, every expenditure made by [the defendant] was traced, including all cashier's checks traced back to their sources to determine how they were purchased. ${ }^{77}$

71. Holland, 348 U.S. at 132-33.

72. Id. at 133 .

73. Id.

74. Id. at 133-35.

75. For an example of an application of "source and application" analysis, see United States v. Terrell, 754 F.2d 1139, 1147 (5th Cir.), cert. denied, 472 U.S. 1029 (1985). In Terrell the IRS examined funds available to the defendant, as reported on prior tax returns, and compared this to expenditures. Its analysis covered preprosecution years 1967 to 1975 . The government establislied that during these years the defendant could not have accumulated sufficient funds to account for the cash he claimed to have on hand at the beginning of the prosecution period because he had expended "nearly $\$ 230,000$ more than his total accumulated funds for the nine-year period covered." Id.

76. Id. at 1139 .

77. Id. at $1147-48$. 
This discussion of the difficulties involved in establishing opening net worth indicates again exactly how inuch is required of the governInent when it seeks to convict a citizen of tax evasion using the net-worth inethod of proof. The process of accuinulating the necessary evidence is labor intensive, time consuming, and in sone cases nearly inpossible. ${ }^{78}$

\section{Proof Problems Created by the Requirement That the Government Establish an Opening Net Worth}

As in the hikely source cases, appellate courts reviewing the government's establishinent of initial net worth frequently ignore the requirements of Holland v. United States ${ }^{79}$ in an effort to accommodate prosecutors who face difficult evidentiary tasks. Holland requires that a reasonably certain opening net worth include all known assets in the schedule of assets. ${ }^{80}$ As discussed earher, absence of an asset can significantly skew the results. ${ }^{81}$ Thus if the net-worth schedule is incoinplete, it is invahd according to Holland and the government cannot use it to carry its burden to establish a tax due and owing.

At least one court has reversed a tax conviction when the government failed to prove all assets. In Merritt $v$. United States ${ }^{82}$ the special agent who investigated the case testified cryptically at trial that sone assets were not included on the net-worth schedule. ${ }^{83}$ The Fifth Circuit refused to speculate on ways that this omission of assets might not be harmful to the government's case and reversed the conviction because

the burden was on the Government to identify these assets and to justify its failure to include them in the net worth schedule.

... It is clear ... that the Government has not established its case until it has established with reasonable certainty an opening net worth. This would include histing or accounting for all assets of the taxpayer of which the Governinent is aware, either through its own investigation or through the checking of leads furnished by the taxpayer. ${ }^{84}$

Other appellate courts-including other panels within the Fifth Circuit-have not held the government to its burden of establishing the opening net worth with reasonable certainty, overlooking the prosecution's failure to mclude all assets im the opening net worth, and have upheld convictions based on insufficient proof of cash on hand. For

78. See id.

79. 348 U.S. 121 (1954). For a discussion of the Holland requirements related to the net-worth area of proof, see supra notes 59-60 and accompanying text.

80. Holland, 348 U.S. at 132.

81. For a discussion of the skewed results that occur when an asset is omitted, see supra text accompanying notes 61-64.

82. 327 F.2d 820 (5th Cir. 1964).

83. Id. at 821 .

84. Id. at 822 . 
example, in United States v. Schafer ${ }^{85}$ the Fifth Circuit Court of Appeals affirmed a conviction although recognizing that the governinent failed to include the defendant's expensive household furniture as an asset. ${ }^{86}$ The court acknowledged that if the defendant had sold the furniture "without realizing a profit and invested the proceeds in stocks, the oinission of furmiture from the beginning net worth coinputation would make it appear that the taxpayer had experienced an ... increase in net worth, namely through an increased investinent in stocks."87 Nevertheless the court found that this possibility did not prevent the government froin carrying its burden of proof because "[i]f such transactions have occurred, the taxpayer has a burden to furmsh 'leads' on thein, so that the government can investigate and perhaps clear the taxpayer prior to trial."88 Nothing in Holland, however, supports requiring defendants to supply leads before they can complain that the government failed to carry its burden of persuasion by preparing an inadequate net-worth analysis. Holland, in fact, stands for the contrary proposition: the governinent must establish the accuracy of the net-worth analysis before a conviction will be upheld.

The Schafer court, however, hike other courts handling this type of case, was faced with a difficult choice. It noted that the government's investigation consuined four years and was exceptionally thorough. ${ }^{89}$ Moreover, the defendant hid assets and constructed a convoluted financial system that was difficult to unravel. ${ }^{90}$ The court was understandably reluctant to reverse a conviction simply because the governinent forgot one itein-furmiture-that probably had little real significance. Still, under Holland the conviction should have been reversed.

Yet a close reading of the Schafer court's coinments about the impressive investigation conducted by the government reveals how the Schafer court was pulled toward affirming the conviction. In fact, the crafting of the Schafer opinion is a real clue to the difficult position in which the court found itself. ${ }^{91}$ For example, the court goes out of its way

85. 580 F.2d 774 (5th Cir.), cert. denied, 439 U.S. 970 (1978).

86. Id. at $778-80,783$.

87. Id. at $778-79$.

88. Id. at 779 .

89. Id. at 777 .

90. Id. at 782 .

91. All good lawyers realize that the emphasis a court places on certain facts in an opinion provides meaningful insight into the sometimes unstated reasons for the holding. Noting which facts are emphasized and the possible importance of this emphasis to the holding is also part of the "law and narrative" approach to legal studies. See generally Papke, Discharge as Denouement: Appreciating the Storytelling of Appellate Opinions, 40 J. LEGAL EDUc. 145 (1990).

The law and narrative approach has much to offer in understanding the appellate opinions at issue in this Article. The courts in these eases expend considerable energy describing the thoroughness of the government's investigation and the mendacity of the defendants. The thoroughness of the government's investigation could conceivably be relevant to the "leads doctrinc" 
to convince the reader that the defendant was a tax cheat ${ }^{92}$ and that the asset neglected by the government was of no consequence. The opinion seems to scold the defendant for failing to raise the issue earher and then punish him by choosing to ignore the possible consequences of the omission on the government's case.

When reading Schafer, one is not offended because an innocent inan was convicted. The opmion convinces the reader that Schafer was guilty. The Schafer opinion is offensive, however, in a more subtle way: the court shifted the burden to the defendant on a necessary fact of the governinent's case. The burden-shifting in Schafer is just as outrageous as

created when the Holland Court required the government in net-worth cases to investigate all leads provided by the defendant that are reasonably susceptible of being checked. See Holland v. United States, 348 U.S. 121, 135-36 (1954). However, the thoroughness of the investigation does not excuse insufficient evidence of likely source or failure to include all assets.

Therefore, a court sends a message when it recounts the thoroughness of the government's investigation, even though it should have no bearing on the problem before the court. A student of the opinion should take note of the message being sent and consider how the fact of the exhaustive investigation affects the ultimate holding. "The restatement of facts is not just a snapshot; it is a composed, compacted narrative." Papke, supra, at 147. Any narrative provides insight into that which coinpels the storyteller.

The goal in a narrative analysis of appellate opinions is to examine the opinion at both an objective, linear level-by analyzing how the opinion lines up against established legal precedentand at the subjective, contextual level-by attempting to explain what unstated motivations have propelled the court to its holding. Moreover, understanding this narrative component assists in understanding the context-driven nature of the judicial approach in these tax cases. For a discussion of this context-driven approach, see infra note 292 and accompanying text.

92. A few quotations froin the opinion will demonstrate this. In the "Background" section of the opinion, the court tells the reader that

[b]y the time of the tax years in issue ... Scbafer began to lead a lifestyle of conspicuous consumption. He accuinulated large, expensive collections of coins and stainps. He purchased diamond rings froin Tiffany \& $\mathrm{Co}$., fur coats and other apparel for women from Bergdorf Goodman in New York, and art work from the Ormond Beach, Florida, Art Galleries. He and his wife purchased two large adjacent lots in Augusta, built a fence along the rear property line, [and] paid substantial sums to an architectural firm to design a 7000 sq. ft. house .... . He also invested heavily in stocks and bonds. Cliarles A. Scliafer had become a man of means.

Schafer, 580 F.2d at 776 (footnotes omitted).

In discussing the sufficiency of the evidence in Schafer the Fifth Circuit noted:

There was evidence of a consistent pattern of under-reporting large amounts of income here. . . . The discrepancy was not due to a single, isolated transaction, but rather to a consistent pattern spread over three years. In addition, Schafer certainly handled his affairs in such a manner as to avoid the usual making of records. He reported no income froin National after he transferred its assets to Custom, although National continued to sell funeral tapes and lie continued to utilize its cliecking account to pay for his purchases. His records of his investments $\mathrm{m}$, and loans to, his other corporations were equally abysmal. The IRS agents were required to construct the financial statements of many of those entities from the ground up, since there were few tax returns filed and grossly inadequate records kept. When the IRS agents attempted to gain access to Cutlass' records for the purpose of investigating the "lead" furnished by the taxpayer, they were met witl obstinate refusals. At least 16 summonses were issued, but the responses were inadequate and the records piecenneal. In fact, one of Scliafer's agents told the IRS agents they would not produce the records "because this was what they were going to base their defense on." The jury certainly could have found that such conduct was desigued to conceal or mislead.

Id. at 782 . 
would be a court's ignoring the prosecution's failure to prove mens reawhen proof of such is an essential element of the case-simply because the defendant offered no leads during the investigation that his mens rea was insufficient for the crime charged. Such burden-shifting is, indeed, offensive on due process grounds. ${ }^{93}$

In United States v. Smith ${ }^{94}$ the Fifth Circuit Court of Appeals again disregarded the government's failure to accurately establish the defendant's opening net worth. The court held that the prosecution's failure to include defendant's bearer bonds as an asset was not fatal to its case. The court based its holding, incoinprehensibly, on the grounds that "[t]he agent was unable to establish the year of acquisition or the cost of the investnent [in the bonds]." 95 This lack of information on the acquisition of the asset, however, provided all the inore reason to reverse the conviction. Because the government could not establish the year the bonds were purchased or for what amount, it was quite possible that the bonds were acquired during or before the opening net-worth year at a high price, and thus that the government's opening net-worth calculation was too low. Such a low opening figure would lead the government to allege a greater increase in net worth than might im fact have been the case. ${ }^{96}$

Similarly, in United States v. Mackey ${ }^{97}$ a conviction based upon an opening net-worth calculation that omitted sonie of defendant's stock holdings was upheld on the grounds that "there was no evidence as to the purchase price [of the stock] or whether the stock was sold at any time."98 But if the stock had been sold during the prosecution period and the proceeds used to purchase assets included in the prosecution period net-worth calculations, the government's failure to account for the sale would have ainounted to a failure to account for a nontaxable source of the alleged net-worth increase.

In United States v. Hamilton ${ }^{99}$ the governnent failed to investigate assets histed by the defendant on a loan application even though the

93. For a discussion of the due process clausc of the fifth amendment and the legality principle, which argues against such an unconscionable burden-shifting device, see infra note 243.

94. 890 F.2d 711 (5th Cir. 1989).

95. Id. at 714 .

96. Recall the earlier hypothetical in which one asset was omitted from $X$ 's opening net worth. See supra notes 61-64 and accompanying text. Omitting one asset from the opening net worth can be critical because it understates the figure that will be compared with subsequent net-worth figures to determine whether net worth increased. Therefore, if including the bearer bonds would increase the opering net-worth calculation by a significant amount while not affecting the prosecution-year net-worth calculation, the difference between the two figures would be reduced. Any increasc in net worth in the prosecution period would therefore be smaller and the alleged unreported taxable income figure lower.

97. 345 F.2d 499 (7th Cir.), cert. denied, 382 U.S. 824 (1965).

98. Id. at 505 .

99. 620 F.2d 712 (9th Cir. 1980). 
application was known to the prosecution. ${ }^{100}$ The Ninth Circuit found nothing wrong with this omission because

[t]he loan apphication made only vague references to some assets allegedly held by appellant in 1967. Only a fraction of those assets were even valued on the application; and that at only $\$ 2500.00$. There was no indication that these assets were sold to produce a cash hoard or that they were the source of nontaxable income. ${ }^{101}$

The Hamilton court ignored, for seemingly specious reasons, the Holland requireinent that all assets be reflected on the schedule of assets. That the assets were only "vaguely" referenced on the application does not alter the possibility that these assets could have been the source of the net-worth bulge. That "there was no indication" that the assets could have accounted for the bulge does not relieve the government of its responsibility to prove that fact in order to sustain its burden.

Looking at the Hamilton case froin the panel's perspective, however, shows once again the difficulties that courts face. The opinion indicates that the court was impressed with the government's investigation and was not inclined to reverse the conviction on the basis of assets that, if properly investigated and added to the opening net worth, were probably insubstantial.

A review of United States v. Terrell ${ }^{102}$ is a fitting conclusion to this discussion. The federal government prosecuted a well-known Texas evangehist for tax evasion using the net-worth method of proof. ${ }^{103}$ The government claimed that the defendant had unreported taxable income in a four-year period of over $\$ 220,000 .^{104}$ The likely source of the networth bulge was the inoney earned through his ministry. ${ }^{105}$ Terrell preached daily and received, im addition to donations to his church, "love offerings" meant for him personally. ${ }^{106}$ To establish Terrell's net worth, the governinent launched a three-and-one-half-year investigation, which the Fifth Circuit noted with admiration. ${ }^{107}$ Unfortunately, the government failed to include one asset in its starting point net worth-a herd of cattle allegedly given to the defendant in a year prior to the indictment period. ${ }^{108}$

The government faced serious probleins in establishing the origin and value of the herd. First, the defendant claimed it was a gift but

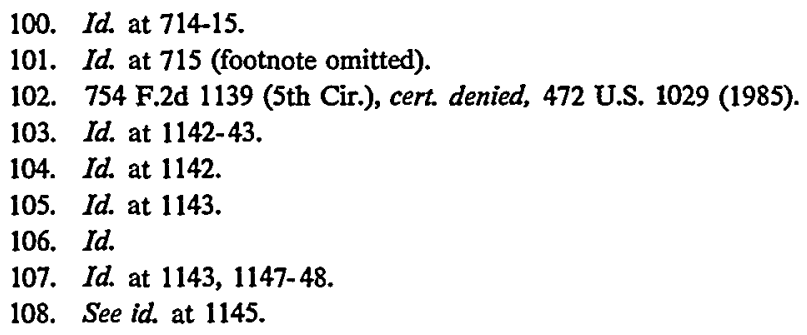


apparently gave no information about the donor. ${ }^{109}$ Second, although the government knew from the defendant's tax returns that he had sold some cattle durmg the prosecution period, it apparently was unaware until late in the investigation that the herd from which the sales came allegedly was a gift. ${ }^{110}$ Rather than attempting to establish the nature of the defendant's acquisition of the herd, its location, size, or the defendant's basis ${ }^{111}$ in the asset, the government assuined that the sale of cattle shown on the tax returns for some of the prosecution years would only generate more unexplained increase in the defendant's net worth. ${ }^{112}$ The government therefore decided, without more investigation, that it need not mclude the cattle in the opeming net-worth calculation. ${ }^{113}$

Despite the difficulties involved in the inquiry, the government should have investigated. As one commentator has noted in reviewing this case, "whether the taxpayer had the herd at the starting point was a fairly simple inatter into which to check - certainly the existence of an entire herd of cattle was a matter more susceptible of being checked than the existence of the cash hoard offered as an explanation in Holland." 114

The Fifth Circuit, however, did not question the government's lack of investigation or the omission of the herd from the opening net worth. Rather, the court attempted to justify the omission by incorrectly interpreting some accounting primciples. ${ }^{115}$ More importantly for purposes of

109. Id.

110. Id. It is not clear from the opinion that this information on the cattle herd actually did come late in the investigation. However, even assuming that the government did not learn that the defendant had received a gift of cattle until close to the end of its investigation, there is no excuse for the government's failure to establish the financial data surrounding the cattle herd. The government knew that the defendant had some cattle-the defendant's tax returns reported the sale of somc part of the herd. This should have been sufficient to trigger an earlier and better investigation than it apparently did.

111. Under the Internal Revenue Code, basis is defined as the cost of property, except as provided otherwise in the Code. See I.R.C. $\$ 1012$ (1988).

112. Terrell, 754 F.2d at 1146 .

113. Id. Apparently the government reasoned that because the defendant had not volunteered any information on the cattle sales, he was trying to hide these sales. And from this the government concluded that Terrell was trying to hide the sales because they generated even more unexplained increase in net worth. This logic is difficult to follow. First, the defendant was not hiding these sales-they were reported on his tax returns. Second, such speculation on motive for concealment, even if true, is not a substitute for proof. Third, without knowing Terrell's basis in the cattle, it is impossible to know what effect the sales had on his net worth. For a discussion of how the cattlc herd's basis could have affected the net-worth calculation, see infra note 115 and accompanying text.

114. 1 D. MCGoweN, D. O'DAY \& K. NorTH, supra note 13, § 23.31, at 861 .

115. The court assumed that the failure to include the herd had no effect on the net-worth calculation because "the only relevance of the herd of cattle already owned by appellant at the beginning of the tax period is to be found in purchases and sales of the cattle during that period." Terrell, 754 F.2d at 1145 . The court was only partially correct in its assumption. It is true that the failure to include the herd in the initial net-worth figure would be relevant if the cattle were sold during the prosecution period. In fact, sale of the herd could have accounted for the bulk of the alleged net-worth increase. But as the government offered no evidence that the herd was on hand at the end of the net-worth period, and thus did not negate the possibility that the defendant sold the 
this Article, the court followed Schafer ${ }^{116}$ by requiring that the defendant provide the government with leads on starting-point assets before permitting the defendant to complain that the government had failed to include such assets on the net-worth schedule. ${ }^{117}$ As we have seen, Holland mandates the opposite result, requiring that the opeming net worth be calculated with reasonable certainty and include all assets. Without a clearly established opening net worth, the government cannot prove a tax deficiency and there can be no conviction. ${ }^{118}$

Once again, though, the court's motives were understandable. Confronted with a diligent government investigation that missed the mark in omitting an asset relevant to only one of four prosecution years, the court in effect looked the other way. ${ }^{119}$ Nevertheless, for at least one of the

herd during the prosecution period, it is clearly not true that the failure to include the herd was without consequence.

The Terrell court compounded its error by apparently finding that because the defendant claimed that the herd was a gift, his basis in it was \$O. In holding so, the court ignored I.R.C. $\$ 1015$ (a) (1988), which provides that a gift's basis is either the basis in the hands of the donor or its fair market value. The only proof of the gift's basis before the court was presented by the defendant, who claimed the herd to be worth around $\$ 75,000$. Terrell, 754 F.2d at 1145 . The prosecution did not investigate the defendant's claim that the herd was donated, and thus was able to offer no proof of the herd's fair market value. Id. As one group of cominentators has noted:

Because the government did not offer proof that the herd was on hand at the end of one or inore of the years at issue and because facts developed during the government's investigation tended to prove that the taxpayer owned the herd at the starting point, the government substantiated, not refuted the [taxpayer's explanation of the alleged net-worth increase as resulting froin the gift of a cattle herd worth $\$ 75,000]$. Because the taxpayer's explanation, including the part about a basis of $\$ 75,000$, was not refuted by the government, the $\$ 75,000$ herd should have been included in opening net worth. . . . ... If the herd had to be included [at a basis of $\$ 75,000$ ], it could have negated gnilt for any year in which the [net-worth] increase . . . was $\$ 75,000$ or less.

1 D. McGowen, D. O'DAY \& K. NoRTH, supra note $13, \S 23.31$, at 861-62.

116. United States v. Schafer, 580 F.2d 774, 779 (5th Cir.), cert. denied, 439 U.S. 970 (1978).

117. Terrell, 754 F.2d at 1146.

118. See Merritt v. United States, 327 F.2d 820,822 ("[i]t is clear . . . that the Government has not established its case until it has established with rcasonable certainty an opening net worth"); $1 \mathrm{D}$. MCGOWEN, D. O'DAY \& K. NORTH, supra note 13, $\$ 23.22$, at 837 ("failure to include all assets in opening net worth is absolutely inconsistent with the theory of this method of proof").

119. The Terrell court concluded that even if the cattle herd should have been included on the net-worth schedule, the omission was harmless becanse the net-worth increase was $\$ 120,000$ for the two prosecution years affected by the herd. Terrell, 754 F.2d at 1146 . The court argued that even with the inclusion of the cattle herd, there was a sufficient net-worth increase to establish unreported income in these two years, and thus to justify the verdict. Id.

This analysis flows from a misconception of basic criminal tax accounting principles. Because each year charged in the indictment is a separate offense, the government has to prove a tax due and owing for each separate year. The government cannot show a tax deficiency for separate years by accuunulating the income figures and then dividing the sum by the number of years charged. See United States v. Boulet, 577 F.2d 1165, 1167-68 (5th Cir. 1978), cert. denied, 439 U.S. 1114 (1979).

Therefore, the Terrell court erred in aggregating two years of the defendant's income. If the defendant did in fact sell the herd of cattle in which he had a purported $\$ 75,000$ basis, he would not have a tax deficiency for the one year in which the net-worth incrcase was under $\$ 75,000$. See supra notc 115. Thus for that year, the government produced no evidence of unreported taxable income. 
Terrell prosecution years, the government failed to carry its burden of persuasion.

Courts are also fudging the proof requirements when cash on hand is at issue. As stated previously, the amount of cash on hand is often difficult to discover. ${ }^{120}$ Cash holdings are by nature private and difficult to verify through traditional paper trails. Further, the target of an investigation may rely on the protection of the fifth amendment and refuse to discuss his financial situation, including the amount of cash he had on hand at the start of the prosecution period. ${ }^{121}$

In some cases the government may be able to infer that the target had no substantial cash on hand at the prosecution's starting point. For example, in Holland the government traced the defendants' finances for decades in order to establish that they had no appreciable cash holdings. ${ }^{122}$ Other cases, however, reveal a judicial leniency in requiring the prosecution to establish a reasonably certain cash-on-hand figure. ${ }^{123}$ United States v. Giacalone ${ }^{124}$ demonstrated how far an appellate court is willing to go to affirm a conviction in cases where the defendant is known to have cash on hand, although the amount cannot be established.

The defendant in Giacalone was a gambler who always had a substantial bankroll available. ${ }^{125}$ However, the defendant refused to discuss his financial position with the government. ${ }^{126}$ Because the government

Indeed, the manner in which the government handled this item could reasonably call into question the entire net-worth computation.

120. For a discussion of the problems the government may have in establishing cash on hand, see supra notes 68-75 and accompanying text.

121. Because cash on hand is so difficult to determine, government investigators try to obtain admissions from defendants concerning their cash holdings during the years under investigation. Thus when targets agree to talk to investigators, IRS special agents are trained to include in the questions a request for a "cash on hand" figure. See United States v. Chu, 779 F.2d 356, 362-63 (7th Cir. 1985) (quoting testimony from IRS agent regarding the questioning of the defendant about his cash on hand).

122. Holland v. United States, 348 U.S. 121, 132-35 (1954).

123. Because cash on hand is part of the opening net worth, it is included within the Holland reasonable-certainty requirement. Consequently, a jury will be instructed that it must find beyond a reasonable doubt that the government established its opening net worth, including cash on hand, with reasonable certainty, and an appellate court will consider whether the evidence was sufficient "for a reasonable trier of fact to conclude that the goverument did establish the defendants' opening 'cash on hand' with reasonable certainty." Chu, 779 F.2d at 364.

124. 574 F.2d 328 (6th Cir.), cert. denied, 439 U.S. 834 (1978).

125. Id. at 332 .

126. Apparently the defendant in this case was among those more notorious citizens who are often pursued for tax crimes. The opinion indicates that he was linked to the disappearance of Jimmy Hoffa. Id. at 333-34. We can infer from this profile, as well as from the appellate opinion's silence on this issue, that the defendant made no admissions regarding the cash-on-hand figure.

In a companion case to Holland, the Supreme Court held that opening net-worth admissions must be corroborated. See Smith v. United States, 348 U.S. 147, 155 (1954). The Court reasoned that "[a]n admission which assumes this importance in the presentation of the prosecution's case should not go uncorroborated, and this is true whether we consider the statement an admission of one of the formal 'elements' of the crime or a fact subsidiary to the proof of these 'elements.' "Id. 
knew of the bankroll, it could not altogether ignore or omit a cash-onhand figure from the opening net worth. Yet without the cooperation of the defendant, the government had no ability to calculate the value of the bankroll.

What fignre for cash on hand did the government use in its opening net-worth estimate? What figure did the government use to prove its prima facie case and to support its burden to establish the opening net worth with reasonable certainty? It used no figure. ${ }^{127}$ It used the dash symbol as an algebraic constant, arguing that because the defendant was a gambler, the "net worth statement assumed the existence of a 'bankroll' of cash which remained approximately the same throughout the period covered." 128 Therefore, without any proof of this stagnant or constant bankroll, the government accounted for the defendant's cash on hand by resort to an algebraic symbol. The government's assumption could not account for an increase im the bankroll if Giacalone had a good year nor could it account for a decrease in the amount after a lean year. Most importantly, it could not account for the reduction of the cash figure through the purchase of assets. It is quite possible that the defendant's net worth may have increased through purchases made with the cash accuinulated from winnings in prior years. These prior-year winnings were not taxable in the prosecution period. Clearly, the government im Giacalone did not establish the defendant's opening net.worth with reasonable certainty. Without such proof, it could not establish that the increases in net worth came from receipts taxable in the years under indictınent.

According to the government, the use of dashes was appropriate because the defendant's financial history showed a negative cash position

This position is in conformity with the general rule that an accused may not be convicted on his own uncorroborated confession. See W. LAFAVE \& A. ScotT, CRIMINAL LAW § 1.4, at 18 (2d student ed. 1986).

However, some courts no longer require the government to corroborate defendant admissions regarding the existence of cash on hand. See, e.g.. United States v. Terrell, 754 F.2d 1139, 1146-47 (5th $\mathrm{Cir}$.) ("the corroboration requirement does not necessarily extend to admissions related to cashon-hand"), cert. denied, 472 U.S. 1029 (1985); United States v. Normile, 587 F.2d 784, 786 (5th Cir. 1979) ("[i]t was not necessary for the government to seek to corroborate the taxpayer's statement"). The courts in these cases rcasoned that because a cash hoard is inherently secret, it cannot be corroborated.

This is nonsense. The issue to be corroborated is not the existence of a hoard, about which only the defendant can know, but the amount of cash the defendant clains is in the hoard. Corroboration is possible by investigating financial history as was done in Holland. In fact, the government often performs exactly this kind of investigation when the cash-on-hand figure given by the defendant is high and the defendant claims that depletion of this cash caused the net-worth increase. See, e.g., Terrell, 754 F.2d at 1146-47; United States v. Giacalone, 574 F.2d 328, 332 (6th Cir.), cert. denied, 439 U.S. 834 (1978). This same kind of investigation should be required as corroboration when the government chooses to accept the defendant's admission regarding the amount of cash on hand.

127. Giacalone, 574 F.2d at 331-32.

128. Id. at 332 (emphasis added). 
in prior years. ${ }^{129}$ But the existence of the bankroll itself indicated that this assumption of a negative cash position was inaccurate. Moreover, if the dashes were permitted because of a negative cash position, then the dashes actually represented the figure $\$ 0$, rather than an algebraic constant, and should have been entered that way on the schedule, as the defendant argued. ${ }^{130}$

The foregoing discussion has illustrated that despite their lip service to the Supreme Court's warnings on the dangers inherent in the networth method of proof, the appellate courts often allow inadequate government proof of net worth by unconstitutionally shifting the burden to the defendant to establish the existence of assets or the amount of cash on hand. Frequently the courts permit this lack of proof out of a recognition that it is simply impossible for the government to ineet its burden of proof. In both the likely source cases and the opening net-worth cases, the government's investigations were typically impressive both in scope and effort, yet unfortunately missed the mark. But missing this mark is not a casual event-it ineans that the government has failed to meet its burden of persuasion on essential elements of the case. Thus in affirming convictions based upon such insufficient evidence, appellate courts disregard not only Supreme Court precedent but also constitutional protections of individual rights.

\section{III}

\section{Corporate Diversions as TaXable Income}

We now turn our attention to another area of crininal tax prosecutions presenting similar probleins of proof: corporate diversions. In a typical corporate-diversion case, the defendant controls a closely held corporation from which he diverts funds. ${ }^{131}$ The difficulty the prosecution faces is in establishing beyond a reasonable doubt that diversions are taxable to the defendant. Once again the problen centers on the tax deficiency element of the tax evasion crime. ${ }^{132}$ If the defendant's receipts were not taxable, then a tax is not due and owing, and the government will have failed to prove one element of the crime charged.

It is the characterization of the diverted funds that presents the difficulty. If the funds diverted are a loan from the corporation to the

129. Id.

130. Id. at 331. The use of dashes to account for cash on hand has been affirmed in other cases. See, e.g., United States v. Scrima, 819 F.2d 996, 999 (11th Cir. 1987) (citing Giacalone with approval and accepting the use of a dash to represent unknown figures).

131. For cases in which the defendant had the controlling interest in such a corporation and diverted corporate funds, see United States v. Curtis, 782 F.2d 593 (6th Cir. 1986); United States v. Thetford, 676 F.2d 170 (5th Cir. 1982), cert. denied, 459 U.S. 1148 (1983); United States v. Miller, 545 F.2d 1204 (9th Cir. 1976), cert. denied, 430 U.S. 930 (1977).

132. For the language of I.R.C. $\$ 7201$ (1988), see supra note 8 . 
defendant, they are not taxable. ${ }^{133}$ If the funds are salary or commission, however, they are taxable in full as ordinary income, and the corporation is entitled to a deduction. ${ }^{134}$ Embezzled funds as well are taxable in full as ordinary income; ${ }^{135}$ dividends entail quite complicated tax consequences. ${ }^{136}$

Proof of the fraudulent nature of a defendant's classification of his funds is difficult and almost always completely circumstantial. For example, although corporate documents may clearly indicate that the diversion was a loan to the defendant as controlling shareholder, ${ }^{137}$ or even a repayment to the defendant of a loan he made previously to the corporation, ${ }^{138}$ the government may have substantial reason to behieve that these entries on the corporate books were fraudulent and designed to conceal evasion of taxes. Problems of proof are no less complicated, unfortunately, even when the defendant diverts funds from the corporation but does not characterize the diversion on any corporate record. ${ }^{139}$ Often the records of the corporation are in such poor condition that reconstructing the nature of various transactions is impossible. ${ }^{140}$

133. See supra note 11.

134. Salary and commission payments are income, see I.R.C. §61(a) (1988), although funds received through a loan are not. Businesses are entitled to deduct salary payments made during the year if the payments are ordinary and necessary to the business and the amount is reasonable. See id. $\S 162(\mathrm{a})(1)$.

135. Not until 1961 did the Supreme Court hold that embezzled funds were income as that tern is defined in I.R.C. $\$ 61$ (1988). See James v. United States, 366 U.S. 213, 221 (1961). Prior to that time the Court had held that because the term income "required both a claim of right to the money, and the absence of a fixed obligation to repay the sums received," embezzled funds were not income. Gardner, The Tax Consequence of Shareholder Diversions in Close Corporations, 21 TAX L. REV. 223 (1966) (discussing Commissioner v. Wilcox, 327 U.S. 404 (1946)).

During the period between Wilcox and James, the IRS attempted to characterize corporate diversions as dividends in order to avoid the embezzlement classifieation. For the IRS this was "the safest way to insure that both the corporation and the shareholder would be taxed on their respective gain from the diverted funds." Gardner, supra, at 237. Once the Supreme Court issued its James decision, however, the IRS no longer felt it necessary to characterize the diversions as dividends in order to avoid the embezzlement issue. Rather, the IRS took the position that no characterization of the funds was necessary and that no matter how classified, the diversion was ordinary income. Id.

136. See infra notes $142-45$ and accompanying text.

137. See Umited States v. Curtis, 782 F.2d 593, 594 (6th Cir. 1986) (holding that distributions from a corporation to its sole shareholder could be characterized as income despite checks upon which the shareholder had written "loan" being deposited by him in corporate accounts).

138. See United States v. Miller, 545 F.2d 1204, 1215-16 (9th Cir. 1976) (upholding tax-evasion conviction even though alleged income to shareholder had been recorded on corporate books as "repayments of loans"), cert. denied, 430 U.S. 930 (1977).

139. See United States v. Thetford, 676 F.2d 170, 175 (5th Cir. 1982) (diversions of "substantial sums" of money not reflected in corporate records), cert. denied, 459 U.S. 1148 (1983); Miller, 545 F.2d at 1215 (defendant "scrambled" corporate books to hide purpose of payments); Davis v. United States, 226 F.2d 331, 333 (6th Cir. 1955) (payments and sales not entered in corporate records), cert. denied, 350 U.S. 965 (1956).

140. For example, in Miller the court noted that the defendant's "scrambling" of the corporate records made it "so that one cannot tell from the records exactly what the payments were intended to be." Miller, 545 F.2d at 1215. 
These problems of proof are exacerbated by the fact that dividends are not required to be formally declared. Dividends may be constructive, and therefore need not be memorialized in a formal record. ${ }^{141}$ Thus, the failure of the corporate books and records to reflect a dividend is not conclusive proof that the diversion was not a dividend.

Further problems arise out of the definition of "dividend" itself. The Internal Revenue Code provides that dividends are taxable as ordinary income. ${ }^{142}$ The Code further provides that distributions out of specified corporate "earnings and profits" are to be regarded as dividends ${ }^{143}$ and that distributions in excess of earnings and profits are to be considered nontaxable return of capital to the extent of the recipient's basis $\mathrm{m}$ the corporation. ${ }^{144}$ Amounts received in excess of both earnings and profits and basis are considered gain froin the sale or exchange of property and taxed accordingly. ${ }^{145}$ Consequently, if a corporation has no earnings and profits, but the diversion is equal to or less than the shareholder's basis in her stock, the diversion may not be taxable to the shareholder regardless of whether the diversion was concealed. Concealment may go to prove intent or willfulness but it does not necessarily alter the classification of a diversion.

\section{A. The Difficulties in Characterizing Diversions}

These tax laws obviously create problems for the prosecution. When the corporate records are scant, nonexistent, or undecipherable, the government will have difficulty proving the nature of the diversion. The government may not be able to determine whether a diversion is a loan, salary, embezzled funds, return of capital, or a dividend. Yet each has a different tax consequence and thus, if the character of the diversion is an intrinsic part or a necessary fact in the proof of the "tax deficiency" element of the crime, as I contend it is, ${ }^{146}$ then the government has the burden under Winship's due process standard to establish this character

141. "The crucial concept in a finding that there is a constructive dividend is that the corporation has conferred a benefit on the shareholder in order to distribute available earnings and profits without expectation of repayment." Truesdell v. Commissioner, 89 T.C. 1280, 1295 (1987).

142. See I.R.C. $\S 301(c)(1)$ (1988).

143. See id. $\S 316(a)$. It is interesting to note that "earnings and profits" is nowhere defined in the Code.

144. Id. \& 301(c)(2).

145. The gain will be taxed as ordinary income unless the stock was a capital asset in the hands of the shareholder, in which case it is taxed as capital gain. See id. I.R.C. $\S \S 301(c)(3), 1001,1221$ 23.

146. For a discussion of why the character of the diversion is a necessary fact in the proof of a tax due and owing, sec infra text accompanying notes 248-49. Essentially the argument is that without proof that a receipt of funds is income rather than a gift, loan, or return of capital, the government cannot show that the defendant failed to report all taxable income or that a tax was due on these funds. If these diverted funds are not income, there is no tax due. Therefore, proof of the character of the diversion is necessary to prove the element of tax deficiency. 
beyond a reasonable doubt. ${ }^{147}$

When corporate records are unclear, establishing the character of a diversion is not easy. For example, establishing the diversion as salary would entail investigating the number of hours worked as well as other payments during this period to the defendant and other employees. The nature of these other payments might provide evidence from which the salary inference would flow. If payments were made on a regular and periodic basis and if taxes were withheld from them, it would indicate that the payments were salary. Furtlier investigation would be required to prove that payments not made witlı sucli regularity were salary. This investigation is inevitably comphicated by the fact that im a small corporation evidence of hours worked by the principal owner may not routinely be recorded.

This same analysis loolds true for embezzlement. If the government has the burden of proving the character of the diversion, then it must establish the elements of the embezzlement crime within the tax case. Proving all the elements of the embezzlement crime, however, may be difficult, ${ }^{148}$ especially considering that many of the corporations from which these funds are diverted are closely held. Consequently, the government must invest a great deal of investigative time and effort with no guarantee of success.

The government may have a somewhat easier time establishing that the diversion was not a loan. The government can subpoena the corporation, ${ }^{149}$ demandimg production of all documents evidencing the loan. If no documents exist, the prosecution then can argue that the failure of the corporation to have documents confirming the loan or its terins is sufficient evidence from which to infer that the diversion was not a loan.

The government's most difficult task, lowever, is sliowing that the diversion was a dividend rather than a return of capital. Because a dividend may be constructive, the government cannot claim that failure of the corporation to declare a dividend is dispositive. Still, the failure of

147. See supra note 4 and accompanying text.

148. One element of the crime of embezzlement is conversion. Another is that the conversion be fraudulent. See W. LAFAvE \& A. ScotT, supra note $126, \S 8.6$, at 729-30. To convert, one has to interfere seriously with ownership rights. In a corporate diversion from a wholly owned business, the defendant, to rebut conversion, could simply testify in his role as chief executive officer and conclude that the diversion did not interfere with the ownership rights of the corporation. Further, he could testify that it was authorized, and therefore not fraudulent.

149. The privilege against self-incrimination found in the fifth amendment to the Constitution only applies to natural persons, and no organization or representative of an organization may use it. Bellis v. United States, 417 U.S. 85, 88-91 (1974) (holding that senior partner of dissolved law firm could not rely on privilege to avoid producing records); United States v. White, 322 U.S. 694, 698701 (1944) (holding that union officer could not nse privilege in refusing to produce records pursuant to grand jury subpoena); Wilson v. United States, 221 U.S. 361, 376-80 (1911) (holding that corporate officer could not use privilege to avoid producing records pursuant to subpoena directed to corporation). 
the corporation to record the diversion as a dividend or return of capital would be helpful proof, depending on the overall state of the corporation's records. Poor records across the board might tend to negate the probative value of the absence of these entries on the records. Therefore, proof beyond a reasonable doubt that a diversion was a dividend rather than a return of capital is nearly impossible if the corporation's records are poor.

If the corporation's records do not make clear that the distribution of funds was a dividend, the government might still be able to sustain its burden by establishing sufficient earnings and profits. However, poor or nonexistent corporatc records also often make proof of earnings and profits difficult. Moreover, if there were no earnings and profits, then the diversion inay be classified as a nontaxable return of capital to the extent of the defendant's basis in the business.

Again, without adequate corporate records, the government investigators would have to mount the cquivalent of a net-worth search to estabhish the defendant's basis. In all likelihood the governinent would have to explore payments the corporation inade at its inception to other entities and payments the corporation made for inprovements, all of which could increase the defendant's basis in the business. Moreover, the investigation might have to include prior corporate years in order to discover whether the defendant received other distributions not from earnings and profits that would have reduced her basis.

It is no wonder, then, that the governinent has taken the position in corporate-diversion cases that it does not have to establish the character of the diversion in order to establish a tax deficiency ${ }^{150}$ and that evidence of unexplained corporate funds in the defendant's hand, or corporate diversions not recorded in the corporate records, is sufficient evidence to satisfy its burden. ${ }^{151}$ Without explicitly stating it, the federal government has taken the position that once it establishes the diversion, the burden then shifts to the defendant to show that the diversion should be classified in a way that either makes it nontaxable or reduces the anount of taxes owed.

\section{B. Appellate Scrutiny in Corporate-Diversion Cases}

Courts have disagreed about whether the government's argument should be accepted. In Truesdell v. Commissioner the United States Tax Court rejected the governinent's position that it did not have to establish the character of the diversion before the diversion would be considered

150. United States v. Williams, 875 F.2d 846, 850 (11th Cir. 1989).

151. United States v. Miller, 545 F.2d 1204, 1215 \& n.13 (9th Cir. 1976), cert. denied, 430 U.S. 930 (1977). 
fully taxable. ${ }^{152}$ The court held that even when a taxpayer has dominion and control over corporate funds and corporate records do not characterize the nature of the diversion, the receipt of these funds is to be taxed as ordinary income only to the extent of earnings and profits. Amounts received in excess of earnings and profits are considered a nontaxable return of capital to the extent of the taxpayer's basis. ${ }^{153}$ As a result of this decision, in civil cases before the Tax Court ${ }^{154}$ the IRS has to estabhish the character of the diversion if it is an issue on which the government has the burden. ${ }^{155}$ The IRS will not be allowed to argue that the diverted funds should be taxed as ordinary income without providing proof of sufficient earnings and profits.

In contrast to the Tax Court's holding, several federal appellate courts have sustained the government's position that it need not establish the nature of the diversions in criminal tax cases. These courts have agreed that proof of unexplained corporate funds in the defendant's hands is sufficient to establish the taxable nature of such funds, and thus to prove a prima facie case. These courts explained their position in a nuinber of ways, none of which justified the anoinaly that the government has greater probleins of proof in a civil case before the Tax Court than in a criminal prosecution. In Davis v. United States, ${ }^{156}$ the first criminal tax case to clearly allow the government to prove the diversion

152. See Truesdell v. Commissioner, 89 T.C. $1280,1296-98$ (1987).

153. See supra notes $142-45$ and accompanying text.

154. The extent to which the Tax Court's decision in Truesdell will apply in the Sixth Circuit is open to debate. The Tax Court previously had given substantial deference to the Sixth Circuit's decision in Davis v. United States, 226 F.2d 331 (6th Cir. 1955), cert. denied, 350 U.S. 965 (1956), even though Davis was a criminal case, and thus was not binding authority in civil matters. In Davis the Sixth Circuit relieved the government of its obligation to prove the character of the diversion. Truesdell holds the exact opposite.

However, the Tax Court did not directly overrule the application of the Davis doctrine to civil cases coming out of the Sixth Circuit. Consequently, in all civil tax cases before the Tax Court, if the government has the burden on the issue, it will have to prove the character of the diversion unless the case is within the jurisdiction of the Sixth Circuit. In that situation, by relying on Davis, the government does not have to establish the character of the diversion, unless in some later case the Tax Court decides that substantial deference should not be given to Davis even in Sixth Circuit civil cases.

155. Usually in Tax Court cases the taxpayer has the burden of proof on the income tax deficiencies at issue. Truesdell, 89 T.C. at 1292-93. However, for some Tax Court issues, the government has the burden. The government, for example, has the burden to establish, by clear and convincing evidence, that the underpayment of tax was due to fraud when the government claims such in its pleadings. See Truesdell, 89 T.C. at 1301; I.R.C. § 7454(a) (1988).

In Truesdell the government asserted some deficiencies in excess of what was stated on the notices of deficiency. Under Tax Court procedure, the government has the burden to establish such excess deficiencies. Truesdell, 89 T.C. at 1296. Therefore, on the issues for which the taxpayer had the burden in Truesdell, he had to show that the diversion did not come from sufficient earnings and profits. In other words, he had to show that the diversion was a nontaxable return of capital. However, on issues for which the government had the burden, the government had to show that the earnings and profits were sufficient to permit the diversion to be fully taxed.

156. 226 F.2d 331 (6th Cir. 1955), cert. denied, 350 U.S. 965 (1956). 
to be ordinary income without also requiring the governinent to establish the character of the diversion, the Sixth Circuit rejected the possibility that the burden of proof had been shifted to the defendant. To the Davis court,

[w] hile, of course, the burden of proof does not shift in a criminal case, it is the rule that when the government establishes a prima facie case, it is then for the defendant to overcome the inferences reasonably to be drawn from the proven facts. Thus, evidence of unexplained funds or property in the hands of a taxpayer establishes a prima facie case of understatement of income, and it is then incumbent on him to overcome the logical inferences to be drawn from such proof. ${ }^{157}$

Under this rationale, any time a small or wholly owned corporation transfers funds to a shareholder, the shareholder risks facing a criminal prosecution if the transfer is unexplained or inexplicable due to poor, lost, or incorrect records. Unless the defendant can produce evidence sufficient to overcome the inference that the diversion is taxable income, this risk remains even if the diversion truly is a loan or a return of capital.

Another court, following Davis, explained its position by contrasting civil and criminal tax issues. In United States $v$. Miller ${ }^{158}$ the Ninth Circuit erroneously argued that, unlike a civil tax case in which the issue is the amount of tax due, in a criminal case the type or specific anount of tax is not of concern. ${ }^{159}$ To the Miller court the only inportant crininal tax issue was whether the defendant had willfully attempted to evade the tax. ${ }^{160}$ This completely ignored the fact that one of the three elements in an evasion case is the existence of a tax due and owing. ${ }^{161}$ In a passage at odds with established criminal tax precedent and constitutional law, the Miller court stated that

[t] he difficulty in automatically applying the constructive distribution rules to this case is that it completely ignores one essential element of the crime charged: the willful intent to evade taxes, and concentrates solely on the issue of the nature of the funds diverted. That latter aspect is not the important element. ${ }^{162}$

157. Id. at 335-36.

158. 545 F.2d 1204 (9th Cir. 1976), cert. denied, 430 U.S. 930 (1977).

159. Id. at 1214.

160. Id.

161. While it is true that in evasion cases the government does not have to establish the exact amount of additional tax due, it still has to prove an additional tax due that is substantially more than the amount reported on the tax return. United States v. Burkhart, 501 F.2d 993, 995 (6th Cir. 1974), cert. denied, 420 U.S. 946 (1975). Miller was correct that an evasion case is not a collection case-the exact amount of tax due is not vital. But Miller was patently wrong when it asserted that the amount of tax due is not important. Some amount must exist and that amount must be substantial. Failure to establish a substantial tax due is a failure to establish one of the crime's elements.

162. Miller, 545 F.2d at 1214 (emphasis in original). 
In this passage the Miller court remarkably contends that one statutory element of a crime is more important than another. ${ }^{163}$ Nothing in constitutional law allows a court to value one element of a crime more than another. One does not commit burglary if one does not "break the close." One does not commit murder if one does not kill someone. And one does not commit tax evasion if there is no tax deficiency, no matter what the intent. As was stated before, witliout establishimg that the diversion is taxable, no tax is due and owing, and there can be no crime.

Why are appellate courts willing to shift the burden and ignore statutory eleinents of the crime in these criminal corporate-diversion cases? Again driven by context, the courts are reluctant, when the probability of guilt seems substantial, to reverse a conviction because the proof required of the government is impossible to obtain. For example, in Miller the defendant repeatedly received liuge diversions and adinitted to instructing his accountant to scrainble the books. ${ }^{164}$ Given the size of the diversions, the economic situation of the corporation, and the intentional disregard of normal bookkeepimg practices, it is understandable why the Ninth Circuit was fairly convinced that the diversion was taxable income to the defendant.

Feeling is not fact, however, and the Miller opimion provided no mdication that the government liad any proof that the diversion was income. The court solved this problem by shifting the burden to the defendant and weighing one element of the crime inore heavily than another. The same set of conflicting feelings characterizes all of these cases: the courts feel that the defendant is guilty and realize that the government would not be able to establish the taxable nature of the diversion if saddled with the burden of proof. ${ }^{165}$ The appellate courts'

163. Moreover, two other courts have followed Miller here. See United States v. Williams, 875 F.2d 846, 851 (11th Cir. 1989) (holding that the governunent need not characterize diverted funds to prove a tax deficiency); United States v. Thetford, 676 F.2d 170, 175 (5th Cir. 1982) (holding that failure to report or record diversion iunplies willful intent to evade), cert. denied, 459 U.S. 1148 (1983).

164. Miller, 545 F.2d at 1210. Interestingly, the defendant clained that the sole purpose of his concealment was to defraud his creditors.

165. For example, in Williams, 875 F.2d at 846, a panel of the Eleventh Circuit discussed in detail the considerable size of the diversions and the defendant's acts to conceal that he held corporate money, inciuding using several bank accounts and cashier's checks. In Thetford, 676 F.2d at 173-74, the court discussed that the defendant instructed employees not to turn over receipts to accountants, told others not to cooperate with the investigation, and paid someone to kill an employee who could not "stand the heat" of the investigation. In Davis v. United States, 226 F.2d at 333 , the evidence recited by the court indicated a pattern of dealing in cash.

One exception to this description of the cases is United States v. Curtis, 782 F.2d 593 (6th Cir. 1986), in which the defendant's innocence was a distinct possibility. While substantial corporate funds were diverted, the defendant did not act to conceal the diversion. The defendant clainied that the funds were loans, and in fact he apparently repaid the corporation periodically. Id. at 594. Moreover, nost of the amounts diverted were reported by the corporation as income. Id. at 596. This case represents a very different situation from the other diversion cases cited in this Article. In 
struggle to affirm these convictions is sad to witness because it is both understandable and wrong.

\section{IV}

\section{INSIDER TRADING AND THE CRIMINAL LAW}

Examining the judicial response to the recent explosion of insidertrading cases $^{166}$ will provide vivid illustrations of courts' allowing the government to prevail in criminal prosecutions despite inadequate proof and will underscore the judiciary's attempt to help prosecutors extricate theinselves froin the proof problems often present in criminal prosecutions involving coinplex commercial behavior. ${ }^{167}$ We shall begin with a brief exammation of the congressional decision not to statutorily define insider trading because it provides the backdrop necessary for understanding why the goverimient's cases often lack the proof required to sustain a criminal conviction.

\section{A. Definitional Difficulties}

Generally, the goverimient faces a number of problems in atteinpting to enforce the securities laws, regardless of whether it does so through civil penalty or criminal sanction. Often these probleins are defimitional. For example, although securities law obviously involves securities, just what the term "securities" encompasses is not at all obvious, and courts atteinpting to define the term have announced decisions that often are difficult both to reconcile and to understand. ${ }^{168}$ In addition,

those other cases, the diverted funds were not entered as income on the corporate books and corporate income tax was not paid on the moneys. The Curtis opinion certainly does not create an overwhelming sense that he was guilty, and in this regard Curtis is very different from the other cases discussed.

The Tax Court does not usually face the pressure to accommodate the government's proof problems that is created when a case has convincing proof of willfulness but insufficient evidence that the diversion was taxable. In the Tax Court the taxpayer usually will have the burden to establish that the diversions were not fully taxable. For a discussion of burdens of proof in the Tax Court, see supra note 155 and accompanying text.

166. Prior to the 1980 s, criminal enforcement of the fraud provisions of the securities law was virtually unknown. Yet between the short two-year period of 1982-84, one-third of all such criminal cases in Seeurities and Exchange Commission (SEC) history were prosecuted. Note, $A$ Critique of the Insider Trading Sanctions Act of 1984, 71 VA. L. REV. 455, 467 (1985).

167. The federal government may seek criminal sanctions under $\$ 24$ of the Securities Act of 1933, 15 U.S.C. $\$ 77 \times$ (1984), and under $\S 32(a)$ of the Seeurities Exchange Act of 1934, 15 U.S.C. $\S 78 \mathrm{ff}(\mathrm{a})$ (1984), if there is a willful violation of any provision of the statute, rule, or regulation thereunder.

168. The Supreme Court has taken the lead in allowing courts to flexibly construe the term "security." In SEC v. C.M. Joiner Leasing Corp., 320 U.S. 344 (1943), the Court held that while the statutory definition of "security" included some obvious investment forms, "the reach of the Act does not stop with the obvious and commonplace." Id. at 351. For a discussion of the cases interpreting the term "security" and the issues raised by these judicial pronouncements, see Steinberg \& Kaulbach, The Supreme Court and the Definition of "Security": The "Context" Clause, 
Congress, desiring the Securities Act of $1933^{169}$ and the Securities and Exchange Act of $1934^{170}$ to apply broadly, extended hability to persons who control those already hable under the acts. ${ }^{171}$ Desiring as well to create as few loopholes as possible, ${ }^{172}$ Congress did not, however, define the term "controlling person." The resulting definitional probleins have given rise to a hodgepodge of law on secondary hability under the 1933 and 1934 Acts, which often gives insufficient notice to those who face prosecution. ${ }^{173}$

The securities laws neither provide a definition of "insider trading" nor, in fact, expressly prohibit it. ${ }^{174}$ Rather, insider trading is usually sanctioned under the general antifraud provision of Rule 10b-5. ${ }^{175}$ Indeed, prior to congressional passage of the Insider Trading Sanctions Act of 1984, ${ }^{176}$ soine commentators argued that Congress did not intend in the 1933 and 1934 Acts to regulate insider trading except in very limited ways. ${ }^{177}$ However, in passing the 1984 Act, Congress evinced intent

\footnotetext{
"Investment Contract" Analysis, and Their Ramifications, 40 VAND. L. REV. 489 (1987) (arguing that Supreme Court decisions in the area of securities law have obscured, rather than clarified, the threshold question about the definition of a "security").

169. Pub. L. No. 73-22, 48 Stat. 74 (codified as amended at 15 U.S.C. $\$ 77 \mathrm{a}-77 \mathrm{aa}$ (1988)).

170. Pub. L. No. 73-291, 48 Stat. 881 (codified as amended at 15 U.S.C. $\S \S 78 \mathrm{a}-78 \mathrm{kk}(1988)$ ).

171. See Securities and Exchange Act of 1934, Pub. L. No. 73-291, § 20(a), 48 Stat. 881 (codified as amended at 15 U.S.C. $\$ \S 78 t$ (a) (1988)); Securities Act of 1933, Pub. L. No. 73-22, $\$ 15$, 48 Stat. 74 (codified as amended at 15 U.S.C. $\S 77$ o (1988)).

172. See H.R. ReP. No. 1383, 73d Cong., 2d Sess. 26 (1934) ("[i]t was thought undesirable to attempt to define the term ["control']" as "[i]t would be difficult if not impossible to enumerate or to anticipate the many ways in which actual control may be exerted").

173. For a discussion of this failure to define the term "controlling person" and the effect that this has had on securities law enforcement, see Note, "Controlling" Securities Fraud: Proposed Liability Standards for Controlling Persons Under the 1933 and 1934 Securities Acts, 72 MINN. L. REv. 930 (1988) (authored by Nancy C. Staudt).

174. Pitt \& Groskaufmanis, Minimizing Corporate Civil and Criminal Liability: A Second Look at Corporate Codes of Conduct, 78 GEo. L.J. 1559, 1588-89 n.175 (1990) (arguing that the federal securities laws, instead of expressly prohibiting "insider trading," simply proscribe the purchase or sale of a security by any person who misstates a material fact or omits a material fact necessary to avoid misrepresentation).
}

175. Rule 10b-5 states:

It shall be unlawful for any person, directly or indirectly, by the use of any means or instrumentality of interstate commerce, or of the mails or of any facility of any national securities exchange,

(a) To employ any device, scheme, or artifice to defraud,

(b) To make any untrue statement of a material fact or to omit to state a material fact necessary in order to make the statements made, in the light of the circumstances under which they were made, not misleading, or

(c) To engage in any act, practice, or course of business which operates or would operate as a fraud or deceit upon any person, in connection with the purchase or sale of any security.

17 C.F.R. $\$ 240.10 \mathrm{~b}-5$ (1990).

176. Pub. L. No. 98-376, 98 Stat. 1264 (codified as amended in various subsections of 15 U.S.C. $\S 78$ (1988 \& Supp. I 1989)).

177. See, e.g., Dooley, Enforcement of Insider Trading Restrictions, 66 VA. L. REv. 1, 55-69 (1980) (examining the legislative history of the 1934 Act and concluding that Congress was not very 
that the Securities and Exchange Commission (SEC) use Rule 10b-5 to curtail the perceived spread of insider trading. Nevertheless, what constitutes insider trading and what is prohibited insider activity remain unclear even after the 1984 Act, partially because Congress once again refused to define "insider trading."178 The absence of an "insider trading" definition has resulted in a series of judicial decisions that have upheld the government's creative atteinpts to curb inside deals despite serious deficiencies in the proof presented. ${ }^{179}$ These cases are now quite famous, and a brief review will help explaim the proof difficulties caused by the failure to define.

The insider trading easiest to regulate is the activity of corporate insiders who use inside information, intended to be available only for corporate purposes, to make market transactions for their own benefit. Other situations, however, present difficult questions. For example, what happens when inside information comes to be possessed by an outsider? Is the key issue whether the trader is an insider or whether the information is confidential and meant to be available only for corporate purposes? Or must both aspects be present-an inside trader with inside information-for the actors to have committed a violation of the securities laws? Without a definition of inside trading, courts have had to decide for theinselves whether 10b-5 extends to the use of material, nonpublic information by outsiders.

The SEC began expansive apphication of Rule 10b-5 to outsiders in

concerned with insider trading); Easterbrook, Insider Trading, Secret Agents, Evidentiary Privileges, and the Production of Information, 1981 SuP. CT. REv. 309, 317-20 (stating that Congress did not intend that the 1933 Act be expansive in the area of insider trading).

178. The reasons stated for this failure to define insider trading range from a desire to insure that the SEC has as much flexibility as possible to combat fraud, to a belief that vague standards arc more intimidating and more prone to stop corruption, to the view that the area is so complex as to preclude definition. For a discussion of the first two views, see Olson, Sturc \& Lins, Recent Insider Trading Developments: The Search for Clarity, 85 Nw. U.L. REv. 715, 729 (1991). The third view was expressed by Senator Alphonse D'Amato in his floor statement aceompanying the Senate passage of the Insider Tradimg Act of 1984. Senator D'Amato, then Chairman of the Subcommitte on Securities of the Senate Committee on Banking, Housing, and Urban Affairs, stated that "[i]n view of the complexity of the undertaking, and the necessity for prompt action on the bill, the committee determmed not to include a defimition of insider trading in this legislation." 130 CoNo. REc. S8913 (daily ed. June 29, 1984) (statement of Sen. D'Amato).

179. Although it is easy to criticize much of the government's creativity in seeking to apply the securities laws to situations that arguably were never intended to be subjeet to securities-fraud control, clearly the government's ardor to stop the use of material, nonpublic inside information comes from a belief that the faith of the investing public in the securities markets ean best be protected by severely limiting the use of inside information. Those who create and enforce the securities laws believe that investor confidence in the fairness of the market is the primary purpose of the securities laws. One can argue that the SEC's actions in the 1980s to vigorously investigate and punish insider trading did more harm to this investor faith than the actual existence of insider trading. Although this may have been the effect, the purpose was to preserve the market through maintaining the willingness of investors to participate in it. 
the landmark administrative decision, In re Cady, Roberts \& Co., ${ }^{180}$ in which it held that a broker who had traded on information he had received from a fellow broker, who was also a director of a publicly traded corporation, had violated the antifraud provisions of Rule 10b-5. Several years later the Second Circuit furthered this expansion in $S E C v$. Texas Gulf Sulphur, ${ }^{181}$ holding that those in possession of material inside information have a duty to disclose the information no matter what relationship they have to the business to which the inside information pertains. ${ }^{182}$ The Texas Gulf Sulphur court based its decision on the premise that all investors should have relatively equal access to material information, and consequently even outsiders with inside information have a duty to disclose. ${ }^{183}$

The Supreme Court rejected the "equal access" position in Chiarella v. United States. ${ }^{184}$ The defendant in Chiarella was an employee of a financial printer. He discovered, through intelligent scrutiny of coded announcements to be primted by his employer, the names of certam companies involved in takeover bids. ${ }^{185}$ Chiarella traded on this nonpublic information, was indicted because of his trading activity, and convicted of violating Rule $10 \mathrm{~b}-5 .{ }^{186}$ The Court reversed the conviction, holding that Rule 10b-5 liability for outsider trading requires a breach of a fiduciary duty. ${ }^{187}$ The Court stated that simply trading on inside information is not sufficient: ${ }^{188}$ there must also be a special relationship between the parties involved. The Court found that Chiarella was not in a fiduciary relationship with the companies involved in the takeover and that, although he had used material, nonpublic - that is, inside-information, neither was he in the kind of relationship to the source of the information necessary for a securities law violation. ${ }^{189}$

However, in a footnote in his dissenting opmion, Chief Justice Burger discussed a way for the SEC to avoid the full impact of the Court's decision. Chief Justice Burger suggested that if the defendant had held a position of trust and confidence with his einployer and had misappropriated information from the einployer, then such a misappropriation could be the basis of hability under Rule $10 \mathrm{~b}-5 .{ }^{190}$ Froin this

180. 40 S.E.C. 907,912 (1961) (stating that traditional insiders do not exhaust the class of persons subject to special duties in connection with trading).

181. 401 F.2d 833 (2d Cir. 1968), cert. denied, 394 U.S. 976 (1969).

182. Id. at 848 .

183. Id.

184. 445 U.S. 222 (1980).

185. Id. at 224 .

186. Id. at 225.

187. Id. at 231 .

188. Id. at 235 .

189. Id.

190. Id. at 239, 243-44 (Burger, C.J., dissenting). 
footnote, the SEC devised and began using what has been termed the "1nisappropriation theory." According to this theory, a person who, in breach of a duty of trust and confidence, inisappropriates material, nonpublic information and uses tliat information to lier advantage in securities transactions is guilty of msider trading. ${ }^{191}$ The SEC's suits against Dennis Levine and Ivan Boesky were largely premised on this theory. ${ }^{192}$

After Chiarella, the SEC did not limit itself to the pursuit of only those outsiders with a fiduciary duty to companies involved in the market transaction at issue. Ratler, the SEC, relying on this misappropriation theory, pursued vigorously those in any position of trust and confidence who had misappropriated inaterial, nonpublic information and used that information to gain advantage in a securities transaction. Obviously, the misappropriation theory significantly increases the number of possible defendants beyond those who would be liable under a strict reading of Chiarella. The theory lias been explicitly adopted by the Second Circuit. ${ }^{193}$

One last line of cases is critical to understanding tlie confusion created by Congress' failure to define insider trading. These cases involve the concept of a "tippee"- a person who receives information from an insider. According to the Supreme Court, tlie tippee may not trade on this material, nonpublic information witlout disclosure if the tippee knows or sliould know that the msider's tip involved a breach of the msider's fiduciary duty. ${ }^{194}$ As we shall see, this requirement of knowledge of the breach causes significant proof probleins for the government.

One final note. As has been discussed, the lack of definition in this area lias required the courts to decide whether the antifraud provisions of Rule 10b-5 apply to outsiders who misappropriate froin positions of trust and confidence and whetler Rule $10 \mathrm{~b}-5$ applies to those who receive information as tippees. The SEC's effort to have courts extend the law to

191. See Olson, Sturc \& Lins, supra note 178, at 717.

192. As a result of these SEC actions, Mr. Levine paid $\$ 362,000$ in criminal fines and spent $\$ 11.5$ million to settle civil charges. He also pleaded guilty to four felony counts and rcceived a twoyear prison sentence. See Wise, Levine Sentence Seen in Line with Insider-Trading Penalties, N.Y.L.J., Feb. 24, 1987, at 1, col. 3. Mr. Boesky disgorged money and paid civil penalties totaling $\$ 100$ million. He also was permanently barred from the securities industry and crtered a guilty plea on felony charges. See Judge Morris Lasker Sentencing Boesky, N.Y.L.J., Dec. 31, 1987, at 6, col. 1.

193. See, e.g., SEC v. Materia, 745 F.2d 197 (2d Cir. 1984) (defendant, an employec of a financial printing company, traded in securities on the basis of material, nonpublic information he misappropriated from his employer and its clients), cert. denied, 471 U.S. 1053 (1985); United States v. Newman, 664 F.2d 12 (2d Cir. 1981) (defendant, a securities trader, traded on the basis of nonpublic information he received from employees of an investment banking firm), cert. denied, 464 U.S. 863 (1983); United States v. Winans, 612 F. Supp. 827 (S.D.N.Y. 1985) (defendant, coauthor of an investment advice column, traded on information he received in his eapacity as author prior to making the information public), aff'd in relevant part sub nom. United States v. Carpenter, 791 F.2d 1024 (2d Cir. 1986), aff'd by an equally divided Court, 484 U.S. 19 (1987).

194. Dirks v. SEC, 463 U.S. 646, 660 (1983). 
cover these outsiders was prompted by its belief that investor faitli in the market would be diminisled by widespread use of material, nonpublic information $^{195}$ and that one goal of securities regulation was to limit the use of sucli information. This public policy rationale for the extension of Rule 10b-5 liability is important for understanding those cases that have allowed the government to prevail in criminal proceedings despite imsuffcient proof.

\section{B. Appellate Enforcement of Insider-Trading Laws}

Perliaps the most discussed misappropriation case is United States $v$. Carpenter. ${ }^{196}$ Altlough the case is known primarily for an equally divided Supreme Court's affirming the Second Circuit's highly controversial use of the misappropriation theory, ${ }^{197}$ it is also an important illustration of proof problems in the securities context. Winans, a reporter for the Wall Street Journal and one of two authors of its daily column, Heard on the Street, entered into a scheme with Peter Brant, a broker witl the firm Kidder Peabody. Winans gave Brant advance information about the contents of the column. Brant would then trade securities, based on the probable impact the column would liave on prices, and sliare any profits with Winans. ${ }^{198}$ The government alleged that David Carpenter, a news clerk at the Journal and Winans' roommate, ${ }^{199}$ was

195. For a discussion of the public policy reasons for the extension of Rule 10b-5 liability, see supra note 179.

196. 791 F.2d 1024 (2d Cir. 1986), aff'd by an equally divided Court, 484 U.S. 19 (1987).

197. See Carpenter v. United States, 484 U.S. 19, 24 (1987). Carpenter is novel because of its broad expansion of the misappropriation theory. As discussed above, all those previously convicted on the basis of the misappropriation of confidential information had been either directly or derivatively in a relationship of trust or confidence with the companies whose stock was being traded. See supra notes $190-93$ and accompanying text. The Wall Street Journal, however, was not in a relationship of trust or confidence with any of the traded companies. Winans' conviction was predicated upon the idea that he was in a position of trust and confidence at the Journal, that he violated this relationship by misappropriating the information obtained by virtue of his position, and that lie used the information for his own personal benefit in the market. Winans, 612 F. Supp. at $840,842$.

198. Carpenter, 484 U.S. at 22-23.

199. In fact, Carpenter and Winans had a hoinosexual relationship that was discussed in the district court's opinion, ostensibly because Carpenter had asserted his spousal relationship with Winans as a defeuse to his involvement in the conspiracy. See United States v. Winans, 612 F. Supp. 827, 848.49 (S.D.N.Y. 1985), aff'd in relevant part sub nom. United States v. Carpenter, 791 F.2d 1024 (2d Cir. 1986), aff'd by an equally divided Court, 484 U.S. 19 (1987). The district court rejected this defense summarily but found, based upon other reasons, that Carpenter was not a participant in the conspiracy. See id. Despite this, the conrt still found it necessary to describe the Winans-Carpenter relationship not just in the portion of the opinion discussing the spousal defense but also on the first page of the court's statenrent of facts. See id. at 829 . It is difficult to see why the nature of the relationship was so important to the trial judge that it should be one of the first facts the reader learns about the defendants. Further, it is easy to speculate about what effect this fact had on the trial judge or the appellate judges. For a discussion of the law and narrative approach, which exaunines what we may conclude from a court's emphasis of certain facts, see supra note 91 . For a 
also involved in the scheine. Though acquitted of conspiracy charges, Carpenter was convicted of aiding and abetting Winans.

The basis for Carpenter's aiding and abetting conviction is less than clear. Neither the district court nor the appeals court specified whether it was based on Carpenter's knowledge of Winans' position of trust and confidence at the newspaper or on Carpenter's own position at the paper. ${ }^{200}$ Under either theory, however, the governinent's proof was insufficient.

For a defendant to be convicted of aiding and abetting in the securities context, the government inust prove that: a breach of duty existed; the aider and abettor knew of the breach; and substantial assistance was given. ${ }^{201}$ In Carpenter, however, the government failed to prove the second eleinent. The evidence was insufficient to support the conclusion that Carpenter knew Winans had breached his duty to the Journal.

A centerpiece of the prosecution's atteinpt to establish Winans' position of trust, and Carpenter's knowledge of Winans' position, was the Journal 's policy regarding einployee confidentiality. The Journal's practice was to inform its new einployees in writing that they were not to use information acquired through their position at the paper for their personal benefit and that such information was to be kept confidential. ${ }^{202}$ The government produced evidence that Winans had received a written stateinent of this policy when he began working for the paper and again when he started writing his column. ${ }^{203}$ The bureau inanager and the chief of the New York bureau both testified that they personally advised Winans of the need for confidentiality. ${ }^{204}$ Moreover, Winans' position as author of an influential column inherently involved confidentiality.

The government produced no evidence that Carpenter knew of the Journal's policy or that he had ever received a written copy of the standards. ${ }^{205}$ Moreover, his position as a news clerk answering phones ${ }^{206}$ can hardly be considered a position of trust and confidence. Thus, the governinent's proof against Carpenter boiled down to the Journal's general practice of supplying a pamphlet on confidentiality to new employees. The government could not even confirm that this general practice was

discussion of whether such facts create a judicial opinion that is driven by context rather than by legal principle, see infra note 292.

200. See Carpenter, 791 F.2d at 1035; Winans, 612 F. Supp. at 848-50.

201. Cf. L. Loss, Fundamentals of SECuRITIEs Regulation 1022 (2d ed. 1988) (discussing requirements for imposing civil liability); see also id. at 234-35 (2d ed. Supp. 1990) (discussing inore recent developments).

202. See Winans, 612 F. Supp. at 829-30.

203. Id.

204. Id. at 830 .

205. Id. at 829-30.

206. Id. at 831 . 
followed in Carpenter's specific case. ${ }^{207}$ Despite the district court's attempt to turn the practice of distributing a pamphlet into a sacred ceremony, ${ }^{208}$ the government's evidence was insufficient to show that Carpenter was in a position of trust, much less that he knew of Winans' position of trust or even that he knew of the Journal's confidentiality policy at all.

Moreover, the district court opinion itself is filled with indications that Carpenter was unaware of his codefendant's scheme. Acquitting Carpenter of conspiracy charges, the court found that "Carpenter never joined the conspiracy .... He initially had a vague understanding of a business arrangement between the three.... The arrangeinent was never substantively discussed in his presence, his participation was never sought until the last month, and ... [he] was never given a share of the profits ...."209 The district court, then, thought it clear that "the government [did not show] beyond a reasonable doubt that Carpenter ever reached any agreement with the other conspirators." 210 The same court, however, convicted Carpenter of aiding and abetting the conspiracy, ${ }^{211}$ finding that Carpenter had helped the conspiracy by "endors[ing] the checks inade out to him by [the other conspirators and] allow[ing] Winans to trade in his name." 212 As was discussed previously, ${ }^{213}$ however, the act of aiding alone is not sufficient for conviction, and the government presented no proof that Carpenter was aware of a breach of duty at the tinie he permitted or engaged in these activities.

In fact the district court opinion is internally inconsistent. According to the court, Carpenter thought Winans was being paid for giving stock advice to the other conspirators. ${ }^{214}$ Further, as Carpenter was not present when the true purpose of the checks was discussed ${ }^{215}$ and the checks were deposited into Winans and Carpenter's joint account, it is not iniplausible that Carpenter believed that the checks were for legitimate financial advice. Carpenter cannot be guilty of aiding and abetting if, by the district court's own adinission, he "had [only] a vague understanding of a business arrangenent between" the conspirators and did not know of the underlying breach of duty at the time that he performed the action that gave assistance to the conspiracy.

The government also failed to show that Carpenter knew of the con-

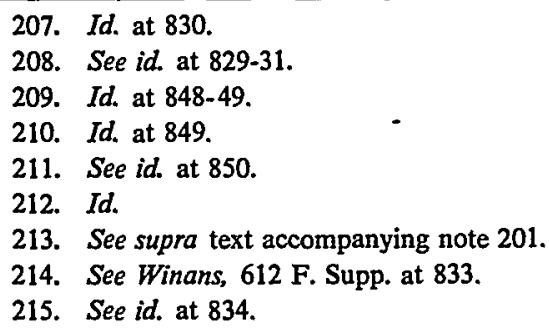


spiracy at the time he permitted Winans to trade in his name. Again, the district court opinion contained evidence indicating that Carpenter's actions were innocent. It is not at all odd that Winans, a stock expert, would trade stock for Carpenter, with whom he had been involved in a "spousal relationship" for almost ten years. ${ }^{216}$ Moreover, Carpenter openly discussed, while at work at the Journal, the stock Winans was trading in his name. ${ }^{217}$ If Carpenter knew of an illegal conspiracy involving a breach of the Journal's confidentiality pohcy, it is extraordinarily unlikely that he would have openly discussed the conspiracy around the Journal.

Other facts recounted in the district court's opinion strengthen the conclusions both that Carpenter did not know about the conspiracy until its final stages and that he was at no time a willing participant in it. Carpenter, when at last he became aware of the true nature of the arrangeinent between the others, took two distimct actions. First, under "substantial pressure" froin the others he produced fake invoices that made it appear as if the checks written to him for illegally made stock profits were instead for decorating services. ${ }^{218}$ The district court inade it clear, however, that these invoices did not in fact give assistance to the conspiracy and, noreover, were of such poor quality that they may have constituted an atteinpt by Carpenter to betray the conspirators. ${ }^{219}$

The second action Carpenter took was to report the scheme to the SEC when the extent of the conspiracy and the severity of the possible consequences became apparent to him. ${ }^{220}$ Both of these actions further bolster a behef that Carpenter did not know of any breach of duty at the time he allegedly aided the conspiracy. Thus with regard to the two specific activities by which Carpenter allegedly aided the conspiracy, there was no evidence presented-and certainly no evidence sufficient to prove guilt beyond a reasonable doubt-that Carpenter knew of the required underlying breach. Indeed, the district court opinion contains a good deal of evidence that indicates Carpenter did not know of the conspiracy. Again, the government successfully obtained a conviction without offering sufficient proof.

What factors encouraged the district court and the court of appeals to accept this inadequate proof? Again, the facts indicated the real possibility that the defendant was guilty. It is quite possible that Carpenter either violated the law or at least beheved he had violated the law. The district court's opinion is replete with references to arguinents among the

\footnotetext{
216. See id. at 829.

217. Id. at 831 .

218. See id. at 849.

219. See id.

220. See id. at 837-38.
} 
members of the trading group, notes written as part of a plan to present a consistent story to the SEC, and the phony invoices created by Carpenter. ${ }^{221}$ All this suggests a guilty mind. Moreover, because Carpenter and Winans were involved in a "spousal relationship," it is possible Carpenter was told of the scheme. Again, the factual context of the case makes Carpenter seem guilty. To seem guilty, though, is not to be proven guilty, and the government offered no evidence to support the district court's conclusion that Carpenter learned increasing amounts about the conspiracy during his tenure at the Journal. ${ }^{222}$

A second reason why Carpenter might have been convicted initially, and the conviction subsequently upheld, is that at the time of this decision, the misappropriation theory had only recently been developed and was under heavy criticism. The Second Circuit might have been motivated to affirm convictions for all defendants in the case, includimg Carpenter, im order to provide a definitive acceptance and expansive interpretation of the new but already beleaguered theory. At a minimum, the Second Circuit would not have been inclined to reverse merely because the prosecution failed to prove that Carpenter received an employee training pamphlet outlining his and Winans' duty of confidentiality. The court undoubtedly realized that personnel changes and fading memories always make such proof extremely difficult.

It is also somewhat difficult to behieve that Carpenter would not know that the Wall Street Journal wanted its news information kept confidential by all news personnel, including news clerks, and especially by authors of influential columns such as Wmans. Given this, a court could reasonably conclude even without the required proof that Carpenter knew or shonld have known that Wimans' position was one of trust and confidence. Unfortunately, this viewpoimt allowed Carpenter to be convicted on these judicial assumptions without the government producing the constitutionally required evidence. ${ }^{223}$

221. Id. at 837,849 .

222. Id. at 850 .

223. The misappropriation theory as extended by Carpenter was applied recently by a district court within the Second Circuit. In United States v. Willis, 737 F. Supp. 269 (S.D.N.Y. 1990), the court denied Willis' motion to dismiss his nidictment for securities and mail fraud. Willis, a psychiatrist, was convicted under Rule 10b-5 for using niformation he received from a patient during counseling sessions. The patient relayed to the doctor facts involving her husband's effort to become CEO of BankAmerica. Id. at 271. The doctor invested based on this information, made a profit, and was indicted. Id. While it is obvious that the doctor had a confidential relationship with the patient, the government offered no proof that the husband told his wife to keep the information confidential. A showing that the information at issue was intended to be kept secret is required even under the most expansive reading of the nisappropriation theory. Yet the governnient apparently offered no proof of this fact in Willis. Although it might seen obvious that the husband would want such information kept secret, assuniptions are not proof. The court, however, felt that assuniptions were enough and concluded that

[t] ]he information inuparted to Mrs. Weill by her husband was, by reason of the nature of 
One last factor might have motivated the Second Circuit to convict Carpenter despite inadequate proof. By adopting the misappropriation theory, the court solidified its position that trading on material, nonpubhic information harms the inarket and the investing public, and thus should be curtailed to the maximum extent possible. Nothing in securities laws or Supreine Court decisions requires the use of the inisappropriation theory, yet the Second Circuit has vigorously adopted and adhered to it. This judicial stance flows, I believe, froin the court's conclusion that the use of inside information, even by outsiders, is dangerous to the investing public's faitl in the market. In light of this, it is not surprising that the Second Circuit convicted Carpenter-its goal is to stop all use of mside information. Again, lowever, it is essential to realize that in its attempt to reach this goal, the court is allowing the government to prevail on insufficient proof, and thus to manipulate the criminal law. This is clearly a case in which, because of the disregard of constitutional requirements, the cure is worse than the disease: allowing such manipulation is a danger altogether greater than the use of inside information by outsiders. ${ }^{224}$

Before concluding this discussion it is only fair to note that here, as in the tax area, courts at times do reverse criminal convictions due to a failure of proof. Recently the Second Circuit, in United States $v$. Chestman, ${ }^{225}$ reversed a conviction in which the government used circumstantial evidence to establisli the defendant tippee's knowledge of the tipper's duty of trust and confidence. Recall that under Dirks v. SEC, ${ }^{226}$ unless a tippee knows or should have known of a fiduciary or confidential relationslip that the tipper breached by passing on the information, the tippee in trading on the information has not violated the securities laws. ${ }^{227}$ The prosecution in Chestman asserted that because the tipper was part of the extended family that controlled the corporation, he owed

that information, the nature of their relationship, and the significance of that information to their personal lives, obviously confidential. . . . Dr. Willis' knowledge or lack of knowledge about whether his patient's husband characterized the information as "confidential" when Mr. Weill discussed it with her is irrelevant.

Id. at 275. It is understandable that a court would want to punish Dr. Willis' behavior. It is also reasonable to assume that the information transmitted by the husband to his wife was meant to be confidential. This conclusion, however, does not rise to the level of proof beyond a reasonable doubt. The doctor's knowledge of the confidential nature of the information is not irrelevant. Rather, it is essential proof that the doctor did more than violate his patient's trust in him. It is essential proof that the doctor willfully committed a fraud on the market prohibited under Rule 10b-5.

224. Moreover, the use of civil penalties can effectively deter insider trading-the civil penalty for msider trading is potentially three times the profit gained or loss avoided due to the unlawful trading. See 15 U.S.C. $\$ 78 \mathrm{u}-1(\mathrm{a})(2)$.

225. 947 F.2d 551 (2d Cir. 1991) (en banc).

226. 463 U.S. 646 (1983).

227. For a discussion of Dirks, see supra note 194 and accompanying text. 
a fiduciary duty or its functional equivalent to that family. ${ }^{228}$ It claimed that in relaying information of an impending takeover to Chestman, he breached this duty. The court found, however, that the flexible definition of "fiduciary" used in other areas of the law was inappropriate in the area of securities law. ${ }^{229}$ The court determined that a marital or family relationship alone is not enough to establish a fiduciary duty and that as the prosecution presented little else to establish the relationship, the evidence was insufficient to support the conclusion that such a relationship existed. ${ }^{230}$ Because the government had relied on this relationship to estabhisl that Chestman's tipper had a duty of confidentiality, the court held that the prosecution had failed to estabhish the predicate violation of fiduciary duty necessary for Chestman to be convicted under the misappropriation theory. ${ }^{231}$

Chestman highlights the government's investigative and proof problems. Establishing the tipper's duty may involve tracing relationships and complicated financial dealings. Proving the tippee's knowledge of the breach of this duty can entail investigating a course of dealing in order to establisli the tippee's awareness of the tipper's confidential relationship. It is understandable tliat a court considering an insider-trading prosecution may be teinpted to look to burden-shifting devices to accominodate these probleins for the prosecution. The Chestman court, on the contrary, recognized the difficult issues involved in the application of the misappropriation theory, indicating that it would "tread cautiously in extending the misappropriation theory to new relationships, lest [its] efforts to construe Rule 10b-5 lose inetliod and predictability."232 Other courts would do well to choose caution and not be content to blithely sustain convictions based upon evidence that fails to meet constitutional standards. ${ }^{233}$

228. Chestman, 947 F.2d at 570.

229. Id. at 569 .

230. Id. at 567-68, 570-71.

231. Id. at 571 .

232. Id. at 567.

233. It is interesting to note that in his dissent from the reversal of Chestman's convictions under 10(b), Judge Winter, joined by Chief Judge Oakes and Judges Newinan, Kearse, and McLaughlin, argued for the imposition of a duty of confidentiality between certain fainily members. See id. at 579-80 (Winter, J., concurring in part and dissenting in part). Under Winter's proposed test, the prosecution need not present any evidence indicating either that the counmunication in question was understood by both parties to be confidential or that prior dealings between the parties would indicate as much. See id. The prosecution, it seems, would merely need to show that a familial relationship existed. Winter's motivation for proposing this lowered standard seems twofold, one general to all insider trading cases and one specific to the instant case. First, as Winter noted, under the majority's test, the prosecution, in the absence of factors other than a bare family relation, would need to show "formal, express proinises of confidentiality" between the family members in order to establish a duty of confidentiality. Id. at 580 . This requirement clearly places a heavy burden upon the prosecution. As Winter pointed out, most families do not routinely require 


\section{ForgotTEn CONSTITUTIONAL REQUIREMENTS}

In the net-worth, corporate-diversion, and insider-trading areas we have discussed appellate cases that arguably allow the government to prevail with insufficient proof. In the net-worth cases, rather than following the lead of Holland v. United States ${ }^{234}$ and United States $v$. Grasso $^{235}$ and requiring proof of a likely source capable of generating the claimed mcrease in net worth, appellate courts have found proof of a possible source of income sufficient, without regard to whether the source could explain the size of the net-worth increase. ${ }^{236}$ Similarly, on the opening net-worth issue, rather than following the lead of Holland and Merritt v. United States ${ }^{237}$ and acknowledging that the burden is on the government to identify all assets-including cash on hand-with reasonable certainty, appellate courts have held that the failure of the defendant to provide leads justified omission of assets from the government's calculations. In the corporate-diversion area, appellate courts following the reasoning of Davis v. United States ${ }^{238}$ tolerate government proof of currently taxable imcome based solely on a showing of unexplained corporate funds in the hands of the defendant. The courts then shift the burden to the defendant to prove the nontaxable nature of these funds. Finally, the enforcement of the securities laws has been marred by definitional difficulties and marked by courts' willingness to infer guilt from context rather than from evidence.

As we have noted, the facts of these cases, when viewed as a whole, seem to indicate the defendant's guilt. ${ }^{239}$ Interestingly, often these appellate decisions appear overly concerned with making it clear that the defendant broke the law. But constitutional protections do not apply only to the innocent. The due process clause of the fifth amendinent ${ }^{240}$

oaths of secrecy from their members, id., and even fewer would have such oaths memorialized. Further, although it is not explicitly stated, it appears that Winter simply felt that the tipper and tippee in this case knew that they were doing something wrong, and therefore that it would not be wrong to hold them accountable. Wimter wrote that "[t]he record fairly brims with Chestman's consciousness that [the tipper] was behaving inproperly." Id. at 581. Winter asserted that "[t]he only explanation for Chestman's and [the tipper's course of conduct] was their consciousness that [the tipper's] trading would be improper." Id. Again, problems of proof and a judicial belief in the probable guilt of the defendant seem to be inotivating a call to lower evidentiary standards.

234. 348 U.S. 121 (1954).

235. 629 F.2d 805 (2d Cir. 1980).

236. See supra notes $36-58$ and accompanying text.

237. 327 F.2d 820 (5th Cir. 1964).

238. 226 F.2d 331 (6th Cir. 1955), cert. denied, 350 U.S. 965 (1956).

239. See supra notes 85-119 and accompanying text for a discussion of cases involving assets oinitted from the net-worth schedule, and supra notes 156-65 and accompanying text for a discussion of cases involving corporate diversions.

240. "[No person] shall be ... deprived of life, liberty, or property, without due process of law ..." U.S. ConsT. amend. V. 
protects a defendant against conviction "except upon proof beyond a reasonable doubt of every fact necessary to constitute the crime with which he is charged."241 We now consider more fully what facts are necessary to constitute the crime charged and what appellate courts look to when they consider challenges to criminal convictions.

Before answering this central question, an understanding of the legal issues not involved $\mathrm{m}$ these decisions will help narrow the discussion. First, statutory affirmative defenses are not at work here. ${ }^{242}$ Congress has created no affirmative defenses to tax evasion or msider trading. Therefore, the debate on the Supreme Court's formalistic approach to elements and affirmative defenses is not apphicable to the due process question at hand. ${ }^{243}$ Second, neither statutory nor clearly stated judicial

241. Cf. In re Winship, 397 U.S. 358, 364 (1970) (applying the fourteenth amendment).

242. The term "affirmative defense" is often nsed

to describe the allocation of a burden, either of production or of persuasion, or both, to the defendant in a criminal case. The burden is fixed by statute or case law at the beginning of the case and does not depend upon the introduction of any evidence by the prosecution. For example, a crime may be statutorily defined as consisting of elements $A$ and $B$. However, the accused may be exonerated or the offense reduced in degree upon proof of $C$. $C$ is an affirmative defense. In some instances, the defendant may simply have the burden of production of evidence with regard to $C$; in the event that burden is satisfied, the prosecution will then have the burden of persuading the jury of elements $A, B$, and $C$ beyond a reasonable doubt. In other instances, the defendant will have both the burden of production and the burden of persuasion. Thus the prosecution will have no burden with regard to $C$; the defendant must both introduce proof of $C$ and persuade the jury of its existence. Usually, the measure of persuasion imposed on the defendant with regard to an affirmative defense is a preponderance of the evidence.

MCCORMICK ON EvidENCE § 346, at 987-88 (E. Cleary 3d ed. 1984) (footnotes omitted) (emphasis in original).

For example, in these tax cases Congress could rewrite the tax evasion statute to place the burden of persuasion on the defendant to prove by a preponderance of the evidence that a corporate diversion was not income. In so doing, Congress would create an affirmative defense.

243. This debate centers on the legislative power to define crimes and defenses and the himits the Constitution places on this power, if any. The Supreme Court appears to have embraced a formalistic analysis of the problem. In cases such as Martin v. Ohio, 480 U.S. 228, 231 (1987) (holding that states may, consistent with due process, characterize self-defense as an affirmative defeuse), and Patterson v. New York, 432 U.S. 197, 201 (1977) (holdimg that states constitutionally may characterize "extreme einotional disturbance" as an affirmative defense to murder), the Court has held that neither due process nor In re Winship preeludes a legislative body from placing the burden on the defense with regard to affirmative defeuses. Rather, in these cases the Court has secimingly adopted a formalistic analysis in which the important factor is whether the matter at issue is classified as an element or an affirmative defense. If the former, then the state has the burden; if the latter, then the state inay give the burden of persuasion to the defendant. Carried to extremes, this suggestion allows a state to transform any element of a crime into an affirmative defense, and thereby shift the burden of persuasion without violating the Constitution. That justices dissented in both Patterson and Martin argues that the Court has not established limits that can prevent states from defining crimes to circumvent Winship.

This formalistic approach is contrasted to what has been termed the "positivist" approach to the problem. Positivists would not make "substance turn on nomenclature." Cole v. Young, 817 F.2d 412, 438 (7th Cir. 1987) (Easterbrook, J., dissenting). To the positivists, the only limits to the legislature's power to define the elements of a crime or to create an affirmative defense is substantive law. If the legislative action in these matters violated substantive due process or the cruel and 
presumptions are a factor in evaluating the legal posture of these decisions. ${ }^{244}$ These cases are simply not decided on the basis of any clearly established presumptions. ${ }^{245}$

unusual punishment clause of the eighth amendment, as examples, then according to the positivists the legislative action can be rebuked by the courts. Otherwise, the legislature is free to define and to allocate burdens of proof. For further discussion of this positivist approach, see Allen, Structuring Jury Decisionmaking in Criminal Cases: A Unified Constitutional Approach to Evidentiary Devices, 94 HARv. L. Rev. 321, passim (1980); Christie \& Pye, Presumptions and Assumptions in the Criminal Law: Another View, 1970 DukE L.J. 919, 933-38; Dripps, The Constitutional Status of the Reasonable Doubt Rule, 75 CALIF. L. REv. 1665, 1677-79 (1987).

There are critics of the positivist approach. See, e.g., Nesson, Rationality, Presumptions, and Judicial Comment: A Response to Professor Allen, 94 HARv. L. REv. 1574, passim (1981); Saltzburg, Burdens of Persuasion in Criminal Cases: Harmonizing the Views of the Justices, 20 AM. CRIM. L. REv. 393, 398-408 (1983). Professor Dripps attacked the positivists' approach because it ignores a "legality principle, according to which the government may not punish one for crime unless that person's conduct violates a contemporary provision of positive law." Dripps, supra, at 1680 . This legality principle, he argued, is central to the procedural safeguards of due process protection, but the principle is more than the procedural safeguards. "The framers [of the Constitution] did not entertain a purely procedural conception of criminal liability. In their day, just as in ours, those whose conduct clearly had not broken a contemporary law could not be put on trial no matter how 'fair' the procedures." Id. at 1682.

Thus, the reasonable doubt standard made part of due process by Winship is not procedural but rather enforces the legality principle. "[T] he reasonable doubt rule is not a safeguard against the loss of state statutory entitlements. Rather it is a safeguard against the loss of constitutionally recognized liberty except as provided by law." Id. at 1717. Consequently, under this approach, legislative action that thwarts the legality principle violates the due process clause not as a matter of procedure but as a matter of substance.

In any event, while the debate on the power of the state to create affirmative defenses does not particularly apply to the issues addressed in this Article, it underscores that burden-shifting in criminal cases, even when articulated and done by the legislature, is controversial and has unresolved constitutional implications.

244. For purposes of this Article, "presumption" is defined as a "standardized practice, under which certain facts are held to call for uniform treatment with respect to their effect as proof of other facts." MCCORMICK ON EvideNCE, supra note $242, \S 342$, at 965 . The terin is difficult to define because in different contexts it can mean either a shift both of the burden of persuasion and production or a shift only in the burden of production. In the criminal law it often is used to mean a standardized rule that perinits an inference of one fact from another. Id. at 966. Thus, a presumption is different from an affirnative defense because an affirunative defense is intended to allocate either the burden of production or persuasion to the defendant while a presumption does not necessarily do either. Obviously, an affirnative defense and a presumption can have the same effect, depending on the specifics of each.

For purposes of this Article, the important part of the definition of presumption is that it is standardized - that is, its operation is known and stated so that a defendant is aware of the presumption's operation and possible effect. Hence, presumption could be defined simply as "any standardized rule which perinits the inference of one fact from another . . . regardless of whether the rule operates to shift the burden of production." Id. $\S 346$, at 988 .

245. In the criminal tax cases discussed in this Article, the courts do not phrase the proof issues in terms of presumptions or affirmative defenses. Rather, a court will instruct a jury that it may infer some facts from the existence of other facts but that it does not have to so infer. The phrasing of such instructions, to permit but not require an inference, is likely a reaction, in part, to the Supreme Court's decisions in Sandstrom v. Montana, 442 U.S. 510, 514 (1979) ("[t]he threshold inquiry in ascertaining the constitutional analysis applicable to this kind of jury instruction is to determine the nature of the presumption it describes"), and County Court v. Allen, 442 U.S. 140, 157 (1979) (perınissive presumption "allows-but does not require-the trier of fact to infer the elemental fact 


\section{A. The Rational Fact Finder Test}

A genuine understanding of the basis of the decisions I have discussed inust embrace not only the exphicitly stated reasons for the holding but also the frequently unstated rationale. Exphicitly, these cases are decided under the "rational fact finder" test devised in Jackson $v$. Virginia. ${ }^{246}$ This test requires that a jury verdict be upheld only if "after viewing the evidence in the light most favorable to the prosecution, any rational trier of fact could have found the essential elements of the crime beyond a reasonable doubt."247

Given this standard, and reviewing the cases and issues discussed in this Article, the question is whether the evidence in a given case is sufficient to pass this test. Clearly, in inany of the cases discussed the government failed to offer sufficient proof. For example, without proof in a networtli case of a likely source sufficient to generate the net-worth increase, or alternatively the negation of all nontaxable sources, the government has absolutely no evidence of currently taxable income. Without proof of all assets at the opening net wortll, the prosecution is without evidence that the increase in wortl did not come from a sale of an absent asset and again is without any proof that the net-worth increase establislies currently taxable imcoine.

The same analysis applies to the corporate-diversion situation. Proof thiat a defendant has unexplained corporate funds does not amount to proof that the funds represent currently taxable income. Without proof of the character of the diversion, the government is without evidence that a tax was due and owing. Similarly, in insider-trading cases the government cannot prove aiding and abetting or a tippee's violation of securities laws unless it can prove that the defendant knew that a relationship of trust and confidence had been breaclied. Because inany of the

from proof by the prosecutor of the basic" facts and does not shift the burden of proof to the defendant).

In these two cases the Court distinguished between mandatory and permissive presumptions and defined permissive presumptions as ones that allow, but do not mandate, the jury to infer presumed facts from proof of basic facts. Distinguishing betwecn mandatory and permissive presumptions is important because strict judicial scrutiny is required when reviewing mandatory presumptions in order to ensure that a rational fact finder could find the presumed fact beyond a reasonable doubt, while permissive presunptions are reviewed less harshly. For further discussion of mandatory and permissive presumptions, see infra note 261 and accompanying text.

Courts do not state directly in criminal tax cases that presumptions, even permissive ones, are at work in the government's proof. However, in jury instructions courts do inform the trier of fact that it unay infer certain facts from the proof of other basic facts. In that sense, then, courts are instructing juries on the use of permissive presumptions, as the term "permissive presumption" has been defined by the Supreme Court.

246. 443 U.S. 307 (1979).

247. Id. at 319 (emphasis in original). 
cases discussed allow the government to proceed despite this lack of proof, they violate Jackson v. Virginia and In re Winship.

The Jackson v. Virginia test, of course, is one that looks to all the evidence, not just evidence produced by the government. Yet even when all the evidence is considered, the cases under review fail to meet the standard. For exainple, in United States v. Miller, ${ }^{248}$ a corporate-diversion case, the evidence that the court examined on appeal focused solely on the element of willfulness rather than on proof of income. In response to the defendant's argument that the government failed to prove the diversion was income, the court claimed that the only element it need consider was willfulness. ${ }^{249}$

Similarly, in United States v. Schafer ${ }^{250}$ and United States v. Terrell ${ }^{251}$ no evidence was produced showing that the missing asset was not the reason for the net-worth increase. Therefore, there was no proof that the net-worth increase was attributable to currently taxable mcome. ${ }^{252}$ And in cases such as United States $v$. Costello, ${ }^{253}$ the capacity of the likely source to generate the net-worth increase was simply never established, leading once again to the conclusion that there was no proof that the net-worth increase was attributable to currently taxable imcome.

In all these tax cases the courts considered many pieces of evidence, all of which went to prove willfulness but none of which established income. ${ }^{254}$ Thus even on the basis of their stated legal standard for review, Jackson v. Virginia, these cases failed to comport with constitutional requirements.

248. 545 F.2d 1204 (9th Cir. 1976), cert. denied, 430 U.S. 930 (1977).

249. Id. For a discussion of the Miller case, see supra notes $158-63$ and accompanying text.

250. 580 F.2d 774 (5th Cir. 1978), cert. denied, 439 U.S. 970 (1978). For a discussion of Schafer, see supra notes $85-93$ and accompanying text.

251. 754 F.2d 1139 (5th Cir.), cert. denied, 472 U.S. 1029 (1985). For a discussion of Terrell, see supra notes 102-19 and accompanying text.

252. Terrell, 754 F.2d at 1145-46.

253. 221 F.2d 668 (2d Cir. 1955), aff'd, 350 U.S. 359 (1956). For a discussion of Costello, see supra note 54 and accompanying text.

254. These cases could possibly have been decided upon a rationale similar to that of Thompson v. City of Louisville, 362 U.S. 199 (1960), in which the Supreme Court struck down a conviction because it was not supported by any evidence, and thus amounted to a denial of due process. If it is true, as asserted in this Article, that the government is failing to produce any evidence of currently taxable income, and therefore failing to produce any evidence of a tax deficiency, then arguably the Thompson no-evidence doctrine applies to these cases. However, because even a "modicum" of evidence may satisfy the Thompson doctrine, Jacobellis v. Ohio, 378 U.S. 184, 202 (1964) (Warren, C.J., dissenting), the "Thompson doctrine simply fails to supply a workable or even a predictable standard for deterniming whether the due process command of Winship has been honored." Jackson v. Virgimia, 443 U.S. 307, 320 (1979). 


\section{B. Implied Presumptions and Their Constitutional Flaws}

Beneath the surface of these decisions, however, one can see a more complicated approach by the courts that might explain these cases. Arguably these courts are using-perliaps witlout realizing it and certainly witliout stating it-presumptions to resolve these matters. We may call these implied, or even perliaps constructive, presumptions, which are unstated yet important. Clearly these constructive devices have been created for the same reason affirmative defenses and articulated presumptions are created-to reallocate a burden, either one of prodnction or persuasion. ${ }^{255}$ The judiciary's perception tlrat such a reallocation is necessary in criminal tax and securities cases undoubtedly results from its awareness of the prosecutorial proof problems. ${ }^{256}$ Althouglı such devices are definitely helpful to the government, the question is whether these implied presumptions are constitutional.

First, we must define tliese constructive devices and explain wliat it is that the courts are doing. Framing these devices in specific terms is a necessary first step in testing their constitutionality. The implied presumptions can be described as follows:

1. In a net-worth evasion case, a jury may find currently taxable income sufficient to account for the net-wortl increase if it finds beyond a reasonable doubt a possible source of taxable imcoine.

2. In a net-worth evasion case, a jury may find currently taxable income from an incomplete operning net worth-tliat is, a net worth that oinits assets-if it finds beyond a reasonable doubt that the defendant did not provide leads to the government during the investigation pertaining to the omitted assets.

3. In a corporate-diversion case, a jury may find currently taxable

255. Academic discourse on the creation of presumptions usually focuses on certain policy reasons. Among these are: (1) to make a certain contention difficult to prove because it is not favored for public policy reasons; (2) to make the party with the greater access to the facts responsible for its proof; or (3) to save time because it is so probable that proof of one fact establishes the presumed fact. MCCORMICK ON EvIDENCE, supra note 242, $\$ 342$, at 968.

256. Some will no doubt argue that in these criminal tax cases courts are simply stating reasonable inferences, and if such judicial action is construed as creating a presumption, it is only a perfectly proper permissive presumption. This argument is wrong for several reasons. First, as discussed infro notes 257-67 and accompanying text, the courts often do not state which burdenshifting device they are using, and therefore one has no way of knowing if the device is a permissive presuinption, inference, or mandatory presumption. Second, because the governinent often offers no proof from which anything can be inferred, it is unlikely that the courts are simply relying on reasonable inferences. For example, if taxable income may be inferred only by finding proof of a sufficient likely source or by negating nontaxable sources, then without the nccessary proof, the inference cannot reasonably be drawn. As we have seen, often the government prevails without offering proof of sufficient likely source or negating nontaxable sources. The government, therefore, must be prevailing by operation of a device that allows the jury to find taxable income without reference to another item of proof. This kind of fact finding is not done by inference. It is done by mandatory presumption. 
income if it finds beyond a reasonable doubt that the defendant held unexplained corporate funds.

4. In a securities prosecution for aiding and abetting under the misappropriation theory, a jury may find that a defendant knew of a breach of duty if it finds beyond a reasonable doubt merely that the defendant in fact provided assistance-proof that the defendant knew that the assistance was in aid of a crime is not required.

Two constitutional flaws are apparent in these implied presuinptions. First, the unstated nature of these presumptions violates the sixth amendment and the due process clause of the fifth ainendinent because the defendant receives no clear notice either of what the governinent inust prove or what the defense must negate. For example, a defendant cannot be prepared to produce evidence that the unexplained corporate funds are loans, or that the likely source was inadequate to produce the amount of net-worth increase, if the defendant does not know such proof is expected..$^{257}$

To dismiss this point by arguing that defendants should always be prepared to respond to government charges ignores void-for-vagueness principles. ${ }^{258}$ While the strength of the government's proof may force the defendant to respond to an accusation in some contexts and not rest on his right to remain silent, ${ }^{259}$ a defendant can only prepare for this if

257. The sixth amendment provides that "[i]n all criminal prosecutions, the accused shall enjoy the right . . . to be informed of the nature and cause of the accusation." U.S. CoNST. amend. VI. This provision has been interpreted to require that defendants have sufficient notice of the charges so as to be able to defend against them. Wong Tai v. United States, 273 U.S. 77, 80-81 (1927). In modern practice this requirement that defendants receive fair notice is most frequently seen in voidfor-vagueness cases, which require fair notice under the due process clause of the fifth amendment. W. LAFAVE \& A. Scotr, supra note 126, § 2.3, at 90-91.

While the void-for-vagueness cases are not directly applicable to the issues under consideration here, their rationale is useful for understanding the unfair position in which these tax cases place a defendant. Void-for-vagueness cases usually involve conduct that the defendant probably considered illegal and that could have been criminalized if the state had chosen to do so. The state, however, did not choose to make the statute sufficiently clear to cover the activity at issue, and courts have criticized this kind of prosecution on grounds of unfair notice and arbitrary application of state power. See Dripps, supra note 243 , at 1684-85.

The same rcasoning applies in tax cases. The state should be required to express clearly its desire to shift the burden of production or persuasion to the defendant on the issue of currently taxable income in order to provide adequate notice to the defendant and to prevent the arbitrary application of this burden-shifting device ouly to those cases in which the conduct is particularly egregious or the defendant is particularly notorious.

258. For a discussion of fair notice and void-for-vagueness principles, see supra note 257 and accompanying text. It can be fairly stated that a defendant should always be prepared to defend against the charge as stated in the indictment but that a defendant should never be expected to defend agaiust a mutated form of the charge created by an ad hoc deletion of an element from the government's case.

259. In Turner v. United States, 396 U.S. 398 (1970), the Supreme Court held that an instruction to a jury that allowed it to infer from the defendant's possession of heroin the knowledge that the herom was imported did not violate the defendant's right to remain silent. The Court 
given proper notice. To discover at trial or at the time of jury instructions that the government's failure to prove one element of the charge will be excused by operation of an unannounced presumption is unfair and exactly the kind of government overreaching that the due process clause was intended to prevent. ${ }^{260}$ Second, without a stated and definite nature, it is impossible to know whether such imphed presumptions are mandatory or permissive. As they are phrased above, the imphed presumptions are permissive and thus subject to less scrutiny upon appeal than if mandatory. ${ }^{261}$ However, these constructive presumptions could just as easily be inandatory ones. Their nature is unknown because they operate without having been defined.

For example, with regard to corporate diversions, the presumption could as easily be phrased as follows: "All unexplamed corporate funds in the hands of a defendant are presumed to be currently taxable mcoine in the absence of evidence that would rebut the imphed presumption."262 This phrasing of the corporate-diversion presumption is very close to the language in Davis v. United States ${ }^{263}$ stating that "evidence of unexplained funds or property im the hands of a taxpayer establishes a prima facie case of understatement of incoine, and it is then incumbent on him

concluded that pressure placed upon a defendant to testify as a result of the strength of the government's case was not a violation of the privilege against self-incrimination. Id. at 417-18.

260. For a discussion of the legality principle, see Dripps, supra note 243 . This principle sees due process as requiring that the government "having made the rules, . . must abide by thein. It inay not infer the judgment that one among us has broken the law from a procedure that, in light of the circumstance, is no more than a chance." Id. at 1718. The legality principle would preelude a conviction under the circumstances detailed in the text.

261. Under the Court's holding in County Court v. Allen, 442 U.S. 140, 167 (1979), a pennissive inference or presumption is tested by considering all the evidence in a case im order to determine if the jury could rationally draw the inference. If the inference is rational in light of all the evidence, then use of the inference or presumption will be sustained. This look-at-all-the-evidence approacl to the question of whether a permissive inference unconstitutionally shifts the burden to a defendant las been criticized as ignoring the possibility of the jury convicting solely on the basis of the inference without believing any other evidence. See Allen \& DeGrazia, The Constitutional Requirement of Proof Beyond Reasonable Doubt in Criminal Cases: A Comment Upon Incipient Chaos in the Lower Courts, 20 AM. CRIM. L. REv. 1, 11 (1982).

If the presumption is mandatory, then its use will only be affirmed on appeal if a rational juror could find the presuned fact follows beyond a reasonable doubt from the basic fact. See Francis v. Franklin, 471 U.S. 307, 313-15 (1985) (decision based on due process clause of the fourtecnth amendment); Sandstrom v. Montana, 442 U.S. 510, 520-24 (1979) (prolibiting state froin using evidentiary presumptions in a jury charge that have the effect of relieving the state of its burden of persuasion beyond a rcasonable doubt of every essential element of the crime).

262. The statement of the presuinption in this forn is very close to the language of the presumption held by the Supreme Court in Rose v. Clark, 478 U.S. 570 (1986), to lave unconstitutionally shifted the burden of proof to the defendant. In Rose the unconstitutional presumption stated that " "[a]11 homicides are presuned to be mahicious in the absence of evidence which would rebut the implied presumption." "Id. at 574 (quoting the jury instructions). The Supreme Court in Rose applied the larmless error rule to cases in which a presumption was leld to liave unconstitutionally shifted the burden of proof. Id. at 579-82.

263. 226 F.2d 331 (6th Cir. 1955), cert. denied, 350 U.S. 965 (1956). 
to overcome the logical inferences to be drawn froin such proof."264

If these constructive presumptions are mandatory in operation, then they are unconstitutional unless a rational juror could find the presumed fact beyond a reasonable doubt. ${ }^{265}$ In the example, a rational juror could not find currently taxable income beyond a reasonable doubt from the mere holding of corporate funds. Without precise wording and notice of the presumption, a defendant cannot know if the presumption in operation is mandatory or permissive, and thus will not know how to counter the presumption's use or attack it on appeal. ${ }^{266}$ Jury instructions are prepared too late in the trial process to provide such notice. ${ }^{267}$ On the basis of Jackson v. Virginia as well as the legal status of the use of presumptions in criminal cases, the decisions at issue here ignore certain constitutional principles.

\section{Warnings: Emerging Proof Problems in Other Areas}

As stated at the outset, iny purpose has been to deterinine whether courts' lenient approach to the enforcement of constitutional standards in tax and insider-trading cases is hkely to occur in criminal prosecutions mvolving other complex behavior. The nuniber of penal statutes criminalizing complex commercial and financial behavior is quite large ${ }^{268}$ and seenis to grow regularly, but a simple hist of such statutes does not give the flavor of what the government must prove in order to obtain

264. Id. at 335-36 (citing United States v. Hornstein, 176 F.2d 217, 220 (7th Cir. 1949)).

265. For a discussion of the test applied in evaluating the constitutionality of a mandatory presumption, see supra note 261.

266. Under Sandstrom, the presumed fact must be found beyond a reasonable doubt from the basic fact. See Sandstrom v. Montana, 442 U.S. 510, 523 (1979) (holding jury instructions unconstitutional because state was not required to prove beyond a reasonable doubt every fact necessary to constitute the crime). In a corporate diversion case, if the presumption is mandatory, a jury would have to find beyond a reasonable doubt that currently taxable income existed from the fact that the defendant held unexplained corporate funds. Further, the jury would have to make this finding by referring only to the proof of the basic fact-the holding of corporate funds-without reference to any other evidence in the case. This fact cannot be found to be true beyond a rcasonable doubt under these circumstances. For a discussion of a number of possible characterizations of corporate funds that would not result in finding currently taxable income, see supra notes $133-45$ and accompanying text.

Similarly, if these presumptions are mandatory, a jury would have to find beyond a reasonablc doubt that currently taxable imcome sufficient to account for a net-worth increase existed from the fact that the defendant had a possible source of income or a jury would have to be able to find beyond a reasonable doubt that currently taxable income existed from the fact that the defendant failed to provide information to the prosecution concerning omitted assets.

If these presumptions are mandatory, they will fail the Sandstrom test because the presumed facts cannot be found to be true beyond a reasonable doubt from the basic facts.

267. A court usually does not decide on the final form of jury instructions until sometime after the trial has commenced, and often the court does not confer with counsel on the final wording of jury instructions until after the receipt of all the evidence. Jury instructions thus do not provide sufficient warning to the defendant that she may have to rebut some kind of presumption.

268. For a hist of some of these federal and state statutes, see supra note 1. 
convictions under these provisions. A brief discussion of some statutes should provide a better appreciation that the problems of proof discussed in this Article exist im other areas.

\section{Environmental Control Laws}

The number of criminal statutes is impressive in the enviroumental control area. ${ }^{269}$ For example, the Federal Water Pollution Control Act $^{270}$ imposes criminal liability on any person who, without complying with the statute, willfully discharges any pollutants. In one representative case, United States v. Frezzo Bros., Inc., ${ }^{271}$ the court was faced with tlie question of whether a discharge of manure came from an appropriate agricultural point source, and thus was exempt under the statute from criminal sanction. ${ }^{272}$ In making its determination, the court considered that

"in formulating the criteria for defining agricultural point sources [the Environmental Protection Agency (EPA)] has specifically excluded those sources that may be furrows, ditches, and drains channeling natural runoff, and specifically included irrigation return flow ditches and drains that convey water resulting from its controlled application by man to navigable waters."273

The issue in this case centered on whether agricultural pollution from something other than an irrigation ditch could be subject to criminal penalty under the statute. The statute provided for criminal penalties ouly if agricultural pollution came from irrigation ditches. The Third Circuit remanded to the trial court for a finding on whether the pollution was agricultural. ${ }^{274}$ If it was agricultural pollution, the criminal statute would not apply because the point source for the pollution was not from an irrigation return flow. The trial court, which had avoided the issue imitially, ${ }^{275}$ was forced by the remand to make a finding. It decided that the discharge was not agricultural pollution at all, but rather manufac-

269. Clean Air Act, 42 U.S.C. $\$ \S 7402-7642$ (1988) (criminal penalty found at $\S 7413$ (c)); Federal Water Pollution Control Act, 33 U.S.C. $\$ \S 1251-1387$ (1988) (criminal penalty found at $\S 1319$ (c)); Resource Conservation and Recovery Act of 1976, 42 U.S.C. $\$ \S 6901-6992 k$ (1988) (criminal penalty found at 6928(d)); Comprehensive Environmental Response, Compensation, and Liability Act of 1980, 42 U.S.C. $\$ \S 9601-9657$ (1988), amended by Superfund Amendments and Reauthorization Act of 1986, 42 U.S.C. $\$ \S 9601-9675$ (1988) (criminal penalty found at $\S 9603(b)$ ); Federal 1nsecticide, Fungicide, and Rodenticide Act, 7 U.S.C. $\$ \S 136-136 y$ (1988) (crimmal penalty found at $\S 1361(b)$ ); Toxic Substances Control Act, 15 U.S.C. $\$ \S 2601-2671$ (1988) (criminal penalty found at $\S 2615(b))$.

270. 33 U.S.C. $\S 1319$ (c) (1988).

271. 642 F.2d 59 (3d Cir. 1981).

272. Id. at 61-62.

273. Id. at 62 (quoting 41 Fed. Reg. 7694 (1976)).

274. Id. at 63 .

275. United States v. Frezzo Bros., Inc., 491 F. Supp. 1339, 1342 (E.D. Pa. 1980), rev'd, 642 F.2d 59 (3d Cir. 1981). 
turing pollution, which was subject to the statute without exception. ${ }^{276}$

This case points to possible proof problems for the government in the environmental area. Proof of a discharge point source is critical under the statute. A failure to establish the correct point source from which the pollutant was discharged could destroy the government's case. Thus, as in the tax and insider-trading examples, when the government's proof is weak on point source but the case reeks of willful pollution, such as in Frezzo, ${ }^{277}$ a court may be hesitant to reverse a conviction or direct a verdict for the defendant. Indeed, a court could easily consider examples in the criminal tax area and search for ways to uphold a conviction.

If the evidence necessary to prove a point source beyond a reasonable doubt was information readily available to the defendant, a court could be teinpted to follow the lead of United States v. Schafer ${ }^{278}$ and decide that any flaws in the government's evidence that the defendant has the power to correct will be ignored. A court could follow the winding road of Davis v. United States ${ }^{279}$ and conclude that proof of any unexplamed discharge was prima facie proof that the appropriate point source was the site of the discharge or that the effluent limitations for the pollutant were violated.

\section{Bank Secrecy and Money Laundering}

Legislation creating criminal sanctions with regard to bank secrecy and inoney laundering is relatively new and replete with complicated iteins of proof. ${ }^{280}$ Essentially the statutes "1nake it a crine to do business with or conduct financial transactions for any person who derives lis momes froin certain specified unlawful activities."281 This can have a serious mipact on banks. As one commentator has noted, because the statutes fail to define "criminally derived property," banks and individuals are given no guidance on the scope of the criminal provision. ${ }^{282}$ For exainple, it is unclear whetlier the statutes' prohibitions extend to prop-

276. United States v. Frezzo Bros., Inc., 546 F. Supp. 713 (E.D. Pa. 1982), aff'd, 703 F.2d 62 (3d Cir.), cert. denied, 464 U.S. 829 (1983).

277. The defendants in Frezzo continued to pollute even after four separate visits by EPA regulators. United States v. Frezzo Bros., Inc., 602 F.2d 1123, 1125, 1129 (3d. Cir. 1979), cert. denied, 444 U.S. 1074 (1980).

278. 580 F.2d 774 (5th Cir.), cert. denied, 439 U.S. 970 (1978). For a discussion of Schafer, see supra notes $85-93$ and acconpanying text.

279. 226 F.2d 331 (6th Cir. 1955), cert. denied, 350 U.S. 965 (1956). For a discussion of Davis, see supra notes 156-57 and acconipanying text.

280. Bank Secrecy Act, Pub. L. No. 91-508, 84 Stat. 1114 (1970) (codified as aniended at 12 U.S.C. $\$ \S 1730 d, 1829 b, 1951-1959$ (1982 \& Supp. IV 1986) and 31 U.S.C. $\$ \S 321,5311-5324$ (1982 \& Supp. III 1985), amended by 31 U.S.C. $\S \S 5312(\mathrm{a})(2)(\mathrm{T})-(\mathrm{U}),(\mathrm{a})(5), 5316(\mathrm{a})(1)-(2),(\mathrm{d}), 5317(\mathrm{~b})-$ (c), 5318(a)-(f), 5321(a)(1),(4)-(6),(b)-(d), 5322(a)-(c), 5323(a)-(d), 5324 (1988 \& Supp. 1989)) (specific actions that can lead to convictions for inoney-laundering offenses).

281. Villa, supra note 2, at 497.

282. Id. at 501 . 
erty that is the fruit of criminally derived funds. ${ }^{283}$ In other words, if a cocaine dealer takes his profit and invests in real estate, then sells the real estate and wants to deposit the funds from this sale, there is no way to determine whether the statute makes it a crime for the bank to accept this deposit. Nor is it clear how much time and how many transactions must pass before the money loses its taint. These definitional uncertainties are similar to the problems created by the indeterminacy of the securities laws. ${ }^{284}$

In addition, nothing in the statutes gives any hint as to the extent that criminally derived property taints other property. For example:

If $\$ 25,000$ in illegal proceeds are placed into a bank account containing $\$ 75,000$ in legal inonies, does every check subsequently written on that account consist of $25 \%$ illegal proceeds? If a bank lends a customer $\$ 50,000$ and subsequently learns that an unlawful activity created his source of funds, can it accept repayment of the loan? ${ }^{285}$

Further, how will the government go about proving that a bank or individual conducted a transaction "with the knowledge that the transaction is designed either to conceal some aspect of funds, such as its ownership, control, or source, or to avoid the currency transaction reporting requirements"? ${ }^{286}$ Sorne "designs" to conceal will be just as cornphicated as the proof that funds are "criminally derived property."

Suppose, for example, that the government proves the existence of a fairly elaborate scheme for concealing ownership and further establishes a bank's knowledge that the transaction was designed to conceal ownership. Suppose further that the case smells of corruption and drugs. However, the government fails to prove that the actual funds at issue in this particular indictment were "criminally derived property." In fact, on this issue the only evidence produced by the prosecution establishes that the particular depositor, whose ownership was concealed by the transaction, was convicted two years ago for selling cocaine and that as a result of the conviction he also forfeited property. ${ }^{287}$ The prosecution produces no evidence of current "criminally derived property."

This failure of proof could be analogous to the situation in United

283. Id.

284. Considering such problems, the government no doubt will be somewhat selective in its attempt to enforce these criminal provisions in order to avoid creating any void-for-vagueness precedent in the application of this statute.

285. Villa, supra note 2, at 501.

286. Id. at 496.

287. Under some criminal statutes, forfeiture of certain assets that result from the act giving rise to the forfeiture is a distinct possibility. Statutes providing for forfeiture are: Continuing Criminal Enterprise Act, 21 U.S.C. $\$ 848$ (1988) and Racketeer Influenced and Corrupt Organizations Act, 18 U.S.C. $\S \S 1961-1968$ (1984). The government brings forfeiture proceedings under the Comprehensive Forfeiture Act of 1988, 21 U.S.C. $\S 853(\mathrm{e})(1)(A)(1988)$. 
States v. Costello, ${ }^{288}$ in which the government was unable to prove that a likely source of "indeterminate incoine possibility" actually generated sufficient taxable income in a prosecution year to account for the networth mcrease. Would a court reverse such a conviction? Or would a court, as in the tax and insider-trading cases, carefully detail all the government's proof and the thoroughness of its investigation in an attempt to estabhish that the items proving willfulness also prove that the property was criminally derived? ${ }^{289}$ Would a court use an inphed presumption to vault the hurdles created by the difficult proof issues present in estabhishing criminally derived property or the bank's knowledge of it? ${ }^{290}$

A court likely would feel enormous pressure to resort to soine kind of burden-shifting device analogous to those used in criminal tax and insider-trading cases. Money laundering or bank secrecy indictınents are high-profile prosecutions, often involving the notorious. Moreover, the government may face significant proof probleins even though a thorough investigation was conducted, all of which would create a perfect setting for a court to adopt the saine lenient approach to enforcenient of constitutional standards as seen ni criminal tax cases.

288. 221 F.2d 668 (2d Cir. 1955), aff'd, 350 U.S. 359 (1956). For a discussion of Costello, see supra note 54 and accompanying text.

289. For a discussion of how courts use proof of willfulness in tax cases to justify their decisions to affirm convictions even though the government failed to establish the element of tax deficiency, see supra notes 92 and 164 and accompanying text. This judicial response-using willfulness evidence to find sufficient proof of other elements-is likely to be repeated in the text's hypothetical.

290. In many of the statutes that criminalize complicated commercial or financial activity, the mens rea requirement is willfulness-defined usually as a voluntary, intentional act done with the specific intent to disregard or to disobey the law. See United States v. Pomponio, 429 U.S. 10, 11 (1976) (per curiam) (tax case); Umited States v. Bank of New England, N.A., 821 F.2d 844, 854-55 (1st Cir.) (currency-transaction case), cert. denied, 484 U.S. 943 (1987). Proof of this level of mens rea also poses problems for the government because it requires evidence that the defendant knew what the law was and intentionally disregarded it.

Courts, however, have devised ways to help the government in proving this element. For example, "conscious avoidance" jury instructions are used frequently. Such instructions permit the inference that the defendant knew the law from the defendant's willful blindness to or conscious avoidance of the existence of the law. See id. at 855; United States v. MacKenzie, 777 F.2d 811, 818 (2d Cir. 1985) (tax case), cert. denied, 476 U.S. 1169 (1986); United States v. DeVeau, 734 F.2d 1023, 1028 (5th Cir. 1984) (securities case), cert. denied sub nom. Drobny v. United States, 469 U.S. 1158 (1985). Such instructions allow the government to argue that if the defendant did not know the law, it was only because slie consciously chose not to know it. Further, the jury may infer from avoidance that the defendant acted willfully and did, in fact, intentionally violate a known legal duty.

Courts, in addition, are increasingly affirming the use of the "collective knowledge" doctrine, which allows a jury to find corporate willfulness by aggregating the knowledge of individuals employed by the corporation, even if not one person in the corporation had full knowledge of the law and the corporation's acts in disregard of that law. See Bank of New England, N.A., 821 F.2d at 855-56; United States v. Sliortt Accountancy Corp., 785 F.2d 1448, 1454 (9th Cir.), cert. denied, 478 U.S. 1007 (1986); see also Shirk, Greenberg \& Dawson, Truth or Consequences: Expanding Civil \& Criminal Liability for the Defective Pricing of Government Contracts, 37 CATH. U.L. REv. 935, 97779 (1988) (growing use of the "collectivc knowledge" doctrine in corporate criminal law). 
VI

\section{Conclusions AND Possibilities}

The federal government faces serious obstacles to obtaining the proof necessary to meet its burden im net-worth and corporate-diversion tax prosecutions as well as im prosecutions for imsider tradimg. The cases reveal that even the most diligent attempts by the government to ferret out the facts often fall short. Yet appellate courts frequently affirm convictions in such cases despite such insufficient cvidence and im the process ignore constitutional standards that require the government to prove beyond a reasonable doubt all facts necessary to constitute the crime. Furthermore, in the process of affirming these convictions, appellate courts have created burden-shifting devices that are unarticulated, undefined, and unconstitutional.

Why are courts behaving in this way? One reason, of course, is the natural inclination of appellate courts to affirm convictions. ${ }^{291}$ Yet the extraordinary lengths to which these decisions go in portraying the defendants as transgressors and the government's investigation as thorough and painstaking suggest a different conclusion. Courts are reacting to the overall context of the cases often without regard to the governing legal primciples. These decisions are thus driven by context rather than by legal primciple. ${ }^{292}$ The context is fairly uniform and often includes the

291. This inclination, of course, is driven by notions of judicial economy and deference to the trial court's ability to interpret and apply evidentiary rules. See Leonard, Power and Responsibility in Evidence Law, 63 S. CAL. L. REv. 937, 987 (1990); see also Friendly, Indiscretion About Discretion, 31 EMORY L.J. 747, 759-62 (1982).

292. In making the distinction between context-driven and legal principle-driven, I mean more than the difference between fixed rules and flexible standards. The long-standing debate on the choice between flxed rules and flexible standards remains active. See Leonard, supra note 291, at 989-91. Those who would like the system weighted in favor of fixed rules fear the arbitrariness of a more flexible system. See id. at 990 . Proponents of a system weighted in favor of flexible standards argue that the mechanical application of rules can mean injustice. See id. at 991.

The appellate courts' failure to enforce constitutional principles in the criminal tax area or in other complex prosecutions is tied in part to the flexible standard of review by which the courts evaluate these cases. Specifically, the test articulated in Jackson v. Virginia, 443 U.S. 307 (1979), requires appellate courts to decide the "sufficiency of evidence" by looking at all the evidence in a light most favorable to the government. See id. at 318-19. The flexibility of this standard gives courts (too) much room to maneuver. As one scholar noted in another context, "[t]he review standard itself thus offers appellate courts an easy escape when the review of judgment-based choices would be difficult and time-consuming: simply defer to the trial court and affirm." Leonard, supra note 291 , at 1013 .

However, the difference between fixed rules and flexible standards is only part of what I mean to communicate by the distinction betwecn context-driven and legal principle-driven judicial approaches. By context-driven, I am referring to an approach that: (1) transforms some of the facts into an identifiable context, see supra note 91 ; (2) makes this context the dominant reason for a legal decision; and (3) views the legal principles that should govern the decision as obstacles to be removed or manipulated if they impede the decision mandated by the context. By legal principledriven, I mean an approach that views the legal principles that should goveru the decision as the dominant force in reaching the judgment and that views the facts as important in deciding the 
following items: a prosecution brought in good faith, a defendant whose activities are suspect, to put it generously, and a failure of proof on an element that by its nature is difficult to establish and over which the defendant has control of the production of the facts. Affirming such convictions thus seems "fair" in a moral sense. But it is not fair in a constitutional sense. As the number of prosecutions under these types of statutes contmues to increase, we can ouly expect the unfairness to multiply.

This contextual approach to criminal justice is dangerous for a number of obvious reasons. Context may trap the innocent as well as the guilty. And the power of the state in such cases is aggrandized by devaluing the importance of constitutional guarantees intended to protect individual freedom. ${ }^{293}$

relevance of any particular principle, including whether the principle should be followed, amended, or overturned.

This is not meant necessarily as a criticism of the approach that argues for a greater emphasis on context and contextualized reasoning, an approach often associated with feminist jurisprudence. A feminist approach does not necessarily deny the validity of abstract, deductive reasoning to the resolution of legal issues. Rather, it attempts to give "rationality new meanings . . . [and] acknowledges greater diversity in human experiences." Bartlett, Feminist Legal Methods, 103 HaRV. L. REV. 829, 857 (1990). For example, the contextual approach is defended in feininist jurisprudence because it correctly assumes that political and noral factors are at work in legal judgments, although these are often hidden. Sinilarly, traditional legal reasoning is not always abstract but is also context-driven, although the context is often masked. Consequently,

[f]eminists have found that neutral rules and procedures tend to drive underground the ideologies of the decision-nuaker, and that these ideologies do not serve woinen's interests well. Disadvantaged by hidden bias, feminists see the value of nodes of legal reasoning that expose and open up debate concerning the underlying political and moral considerations.

Id. at 862-63.

My argunient with a context-driven approach is not that it forces us to expand the universe of assumptions upon which our legal principles are grounded. Rather, if the context-driven approach is used to decide an issue without reference and deference to legal principles, judicial decisionmaking becomes arbitrary. Moreover, if a context-driven approach is unspoken and masked behind pronouncements that pay lip service to legal principle, as it is too often in the criminal tax and securities areas, this arbitrariness beconies dangerous. My conclusion, therefore, is that we can identify context, question a context's validity, give voice to a new context, and even decide to abolish a legal principle because a new context deinands that it be abolished. But such an abolition inust necessarily create a new legal principle or all hope of stability and justice is lost. Judicial decisionmakers should be driven by context only to the point of deciding whether the legal principle should apply or whether the context demands that it be abolished. Beyond this point, the fair administration of justice requires that ultimate judgment be driven by legal principle, whether the legal principle is old or newly created. Further, the fair adıninistration of justice inandates that both the context and the legal principle be clearly and directly stated.

And indeed, we have seen in this Article the harm that comes when context is allowed to control decision. The continuing resort to the criminal law in order to regulate coinplex commercial and financial dcalings will result in an increase in judicial decisions that are just as dangerously driven by context as these tax and securities eases.

293. For a discussion of the legality principle, which precludes crininal punishment unless a person's conduct "violates a contemporary provision of positive law," see supra note 243. Professor Dripps defines the legality principle as stating that "[g]uilt is a particular conjunction of law and 
The approach also is dangerous for less obvious reasons. First, deciding cases contextually leads to a habit that will be used reactively even when the result may not appear as "fair." Bending and stretching the law "to fit" in certain cases always has been part of the common-law approach. But bending it too far can stretch it out of shape or cause it to snap. Excessive reliance on context in judicial decisions can become a dangerous habit. Sucli a practice could eventually contribute to a loss of faitl in our system of law.

Second, the contextual approach encourages the government to use crimmal sanctions in inappropriate cases. In the modern regulatory world, the government possesses numerous tools designed to curb undesirable beliavior. For exainple, federal tax laws provide for civil penalties that assess fines for beliavior ranging from the negligent to the fraudulent. ${ }^{294}$ In the securities area, one of the main features of the 1984 insider-trading legislation was an increase in civil penalties. ${ }^{295}$ Similarly, the environmental statutes provide for substantial civil penalties, ${ }^{296}$ and the new insider-trading statutes calculate potential penalties by trebling the profit gained or loss avoided. ${ }^{297}$ Each of these civil penalties lias a significant deterrent effect, and tlus may be used effectively to promote regulatory comphance. At times, of course, the symbolic significance of a criminal prosecution is important in maintaining the rule of law. However, the executive branch should be encouraged both to assess its likehlood of success realistically before bringing a criminal prosecution and to pursue civil penalties when the crimmal case is too difficult to prove.

Third, in a number of ways the contextual approach encourages the legislative branch to create new criminal laws im complex financial and commercial areas. By affirming convictions obtained without sufficient proof and by refusing to clearly and openly articulate that their decisions are driven by context rather than legal principle, the courts fail to provide authority that recognizes low difficult it is to prove tlie elements of some of these criminal statutes. By affirming these convictions, courts also fail to awaken prosecutors to the problems they would face if legal standards were strictly applied. Lacking this awareness, prosecutors are unable to infornn legislatures fully on the difficulties the government may encounter if a new criminal law is enacted.

fact, which exists independently of the procedures employed to identify it. Due process safeguards express a commitment to regulating punishment by law rather than to providing a relatively fair government of functionaries." Dripps, supra note 243, at 1682-83.

294. I.R.C. $\$ \S 6651,6653,6662$ (1988).

295. Pub. L. No. 98-376, § (2)(A), 98 Stat. 1264 (1984) (codified as amended at 15 U.S.C. § 78u (1988)).

296. For a list of environnental statutes that provide for civil penalties, see supra note 269.

297. For a discussion of this statute and its civil penalties, see supra note 176 and accompanying text. 
Lastly, when the contextual approach is used to affirm such convictions, courts fail to provide information to legislatures that will allow these bodies to evaluate rationally the efficacy of using the criminal law to solve society's probleins. Provided with an awareness of the difficulties prosecutors will face if constitutional standards are ever applied, legislatures inay be inore creative in devising reinedies for society's ills rather than simply searching for a cure in the criminal code.

This examination of federal criminal tax and insider-trading prosecutions, therefore, should give us pause as we attempt to evaluate the wisdom of making complex commercial and financial activity subject to criminal sanction. A system of criminal sanctions is iinportant to the concept of deterrence, but criminal sanctions have never been a panacea for social ills. If we continue to rely primarily on the criminal law as a solution, while placing increasing pressure on the judiciary to affirm convictions, we risk creating a system that seeks to accommodate transitory and ill-conceived governmental goals more than it seeks to protect individual rights. 